
\title{
$\begin{array}{ll}\text { Research Square } & \begin{array}{l}\text { Preprints are preliminary reports that have not undergone peer review. } \\ \text { They should not be considered conclusive, used to inform clinical practice, } \\ \text { or referenced by the media as validated information. }\end{array}\end{array}$
}

\section{"LCAT Deficiency: a Systematic Review With the Clinical and Genetic Description of Mexican Kindred"}

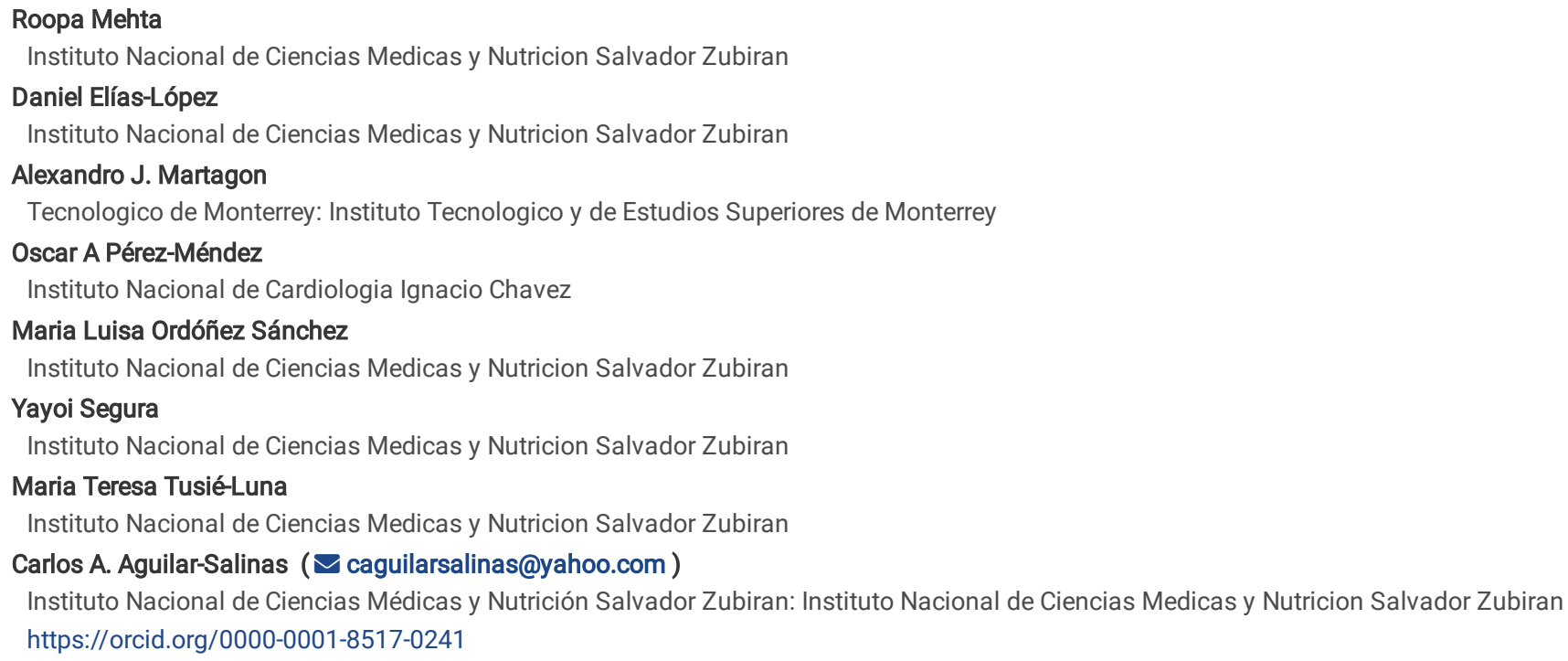

Research

Keywords: LCAT deficiency, HDL cholesterol, ethnicity, coronary artery disease, renal disease, cardiovascular risk

Posted Date: April 9th, 2021

DOI: https://doi.org/10.21203/rs.3.rs-402403/v1

License: (9) (7) This work is licensed under a Creative Commons Attribution 4.0 International License. Read Full License

Version of Record: A version of this preprint was published at Lipids in Health and Disease on July 13th, 2021. See the published version at https://doi.org/10.1186/s12944-021-01498-6. 


\section{Abstract}

\section{Background:}

LCAT deficiency is characterized by two distinct phenotypes, familial LCAT deficiency (FLD) and Fish Eye disease (FED). In this study the results of the first systematic review evaluating the ethnic distribution of LCAT deficiency are shown, with particular emphasis on Latin America with discussion of three Mexican-Mestizo probands.

\section{Methods:}

A systematic review was conducted following the PRISMA Statement in Pubmed and SciELO. Articles which described subjects with LCAT deficiency syndromes and an assessment of the ethnic group to which the subject pertained, were considered for analysis.

\section{Results:}

The systematic review revealed 215 cases (154 FLD, 41 FED and 20 unclassified) pertaining to 33 ethnic/racial groups. There was no association between genetic alteration and ethnicity. The mean age of diagnosis was $42 \pm 16.5$ years, with FED identified later than FLD ( $55 \pm 13.8$ vs. $41 \pm 14.7$ years respectively). The prevalence of premature coronary heart disease was significantly greater in FED vs. FLD. In Latin America, 48 cases of LCAT deficiency have been published from six countries (Argentina (1 unclassified), Brazil (38 FLD), Chile (1 FLD), Columbia (1 FLD), Ecuador (1 FLD) and Mexico (4 FLD, 1 FED and 1 unclassified). Of the Mexican probands, one showed a novel LCAT mutation.

\section{Conclusion:}

The systematic review shows that LCAT deficiency syndromes are clinically and genetically heterogeneous. No association was confirmed between ethnicity and LCAT mutation. There was a significantly greater risk of premature coronary artery disease in FED compared to FLD. In FLD, the emphasis should be in preventing both cardiovascular disease and the progression of renal disease, while in FED, cardiovascular risk management should be the priority. The LCAT mutations discussed in this article are the only ones reported in the Mexican- Amerindian population.

\section{Introduction}

Lecithin cholesterol acyltransferase (LCAT) is a $67 \mathrm{kDa}$ protein, predominantly expressed in the liver (1). It circulates in plasma bound to high density lipoproteins (HDL) but can also be found on apolipoprotein B100 containing particles $(2,3,4)$. It catalyzes the transfer of an unsaturated fatty acid from lecithin to free cholesterol, producing lysolecithin and cholesteryl ester. This reaction occurs on immature HDL particles in the presence of apolipoprotein A-I (apo A-I), and corresponds to the alpha activity of the LCAT enzyme. When this reaction occurs on low density lipoproteins (LDL) or very low density lipoproteins (VLDL) it is referred to as the beta activity. The net result is the formation of hydrophobic cholesterol ester, which is transferred to the lipoprotein core. In the case of HDL, this allows the conversion of discoidal pre-beta 1 particles to mature spherical alpha forms. In addition, the esterification of cholesterol on HDL increases the concentration gradient for free cholesterol between cell membranes and HDL, thus promoting the removal of cholesterol from cells $(1,2)$. Another HDL associated serum enzyme is paraoxonase 1 (PON1), this may play a role in the protection of LDL particles from oxidative stress. Hence, low serum concentrations of HDL may impact susceptibility to vascular disease (3).

LCAT deficiency is a rare autosomal recessive disease $(4,5)$. Loss of LCAT function causes decreased maturation of HDL particles and increased HDL levels of unesterified cholesterol and phosphatidylcholine. There is no reliable estimate of the prevalence of the disease; in individuals with very low HDL cholesterol (HDL-C) ranges, the estimated prevalence of LCAT deficiency is between $2-9 \%(6,7,8)$. The disease is characterized by two distinct phenotypes, familial LCAT deficiency (FLD) and Fish Eye disease (FED). In FLD, both the alpha and beta LCAT activity is lost, leading to extremely low plasma HDL-C (below the 5th percentile for the population), premature corneal opacification, hemolytic anemia, proteinuria and renal failure (9). In FED, only the alpha LCAT activity is lost, the beta activity is preserved, permitting cholesterol esterification on VLDL and LDL but not on HDL (10). As a result, the HDL particles contain only $20 \%$ cholesteryl ester, as compared to 75 to $80 \%$ in control HDL. These individuals present with corneal opacities and low HDL-C levels, but are free of the renal consequences seen in complete LCAT deficiency. Calabresi et al, have suggested that FLD and FED are not two distinct syndromes, but the same disease showing differing levels of LCAT activity (11). Despite distinct cholesterol esterification profiles between FED and FLD, they found that the biochemical phenotype was quite similar; this is further supported by the finding of anemia and renal disease in FED cases.

The clinical phenotype is only apparent in individuals who carry two mutant LCAT alleles (12). The LCAT gene consists of 6 exons, spans 4,200 base pairs and is located on chromosome 16 (16q22) (13). Of the reported mutations, the majority are associated with the FLD phenotype, with a significant number remaining unclassified $(21.5 \%)(14)$.

Mutations in the LCAT gene have been recorded in multiple ethnic and racial groups. However, there is no description of LCAT deficiency in terms of ethnic distribution. In particular, there is sparse knowledge of LCAT deficiency syndromes in Latin America. The greater susceptibility of Hispanics for dyslipidemia (in particular phenotypes with low HDL cholesterol) is a well-documented phenomenon (15). Hispanic ethnicity results from the admixture of native Americans and Spaniards. The Amerindians have suffered catastrophic events (wars, famines, infections), it is likely that genetic selection processes have occurred in this group influencing findings in present day Hispanics (16).

This article reports the results of the first systematic review conducted to explore the distribution of LCAT disorders, particularly those associated with the Amerindian /Hispanic group. In addition, describe the biochemical and genetic investigation of three previously unreported Mexican probands and their kindred with LCAT deficiency syndromes. 


\section{Methods For Systematic Review}

A systematic search was conducted following the PRISMA (Preferred Reporting Items for Systematic reviews and Meta-Analyses) Statement in Pubmed and SciELO. (The PRISMA checklist is shown in supplementary table 1). The initial PICO question was posed as follows: in patients with LCAT disorders (P), the distribution (I) of FLD compared to FED, (C) and the association with ethnicity (especially among Amerindian/Hispanic population(O), is reviewed. Articles which described subjects with a confirmed mutation in the LCAT gene (based on genetic and clinical characteristics) and an assessment of the ethnic group to which the subject pertained, were considered for analysis. All epidemiological, cross-sectional, cohort, retrospective, longitudinal, observational, comparative, case-control and case-reports were considered which contained the following keywords or MeSH terms: Fish eye disease (FED), Familial Lecithin cholesterol acyl transferase deficiency (FLD), LCAT enzyme deficiency (partial and total), LCAT gene mutation or polymorphism, homozygotes, compound heterozygotes, corneal opacities, corneal clouding, low high density cholesterol levels, anemia, renal failure, atherosclerosis. These terms were cross- referenced with the keywords and MeSH terms for ethnicity: minority groups, ethnic groups, African-Americans, Hispanic-Americans, American Native Continental Ancestry Group, Amerindian, Oceanic Ancestry Group, Black, Hispanic, Latino, Asian American, African American, Native American, Indian, Asian, and Pacific Islander. The search algorithm is as follows, i.e. $(((()((()((($ Fish-eye disease) AND (familial lecithin cholesterol acyl transferase deficiency)) AND (partial LCAT enzyme deficiency)) AND (total LCAT enzyme deficiency)) AND (LCAT gene mutation)) AND (LCAT gene polymorphism)) AND (homozygotes)) AND (compound heterozygotes)) AND (corneal opacities)) AND (corneal clouding)) AND (low high density cholesterol levels)) AND (anemia)) AND (renal failure)) AND (atherosclerosis)) AND (each ethnicity previously described)). Articles written in English, Spanish or Portuguese were included. Data collection was carried out by four investigators, commenced in September 2018 and concluded in March 2020. The investigators took care to avoid double counting of cases. In addition, the reference lists of review articles and conference abstracts were also considered. Abstracts were independently assessed to identify eligible research reports. The commonest reasons for ineligibility were, insufficient information regarding either the LCAT gene mutation, clinical characteristics or no mention of ethnicity. This systematic review has been registered in the PROSPERO systematic review register with the ID CRD42021229254.

\section{METHODS FOR BIOCHEMICAL AND GENETIC ANALYSIS OF LCAT PROBANDS}

Biochemical measurements

Fasting blood samples were obtained from all three probands. These included full blood count, chemistry, a complete lipid profile, erythrocyte fragility studies (in FLD deficiency subjects), and 24-hour urine collection for determination of microalbuminuria and creatinine clearance. The lipid parameters were measured in the Institute's central laboratory. For total cholesterol (TC), HDL-C, LDL cholesterol (LDL-C), triglycerides and glucose measurements commercial enzymatic methods were used (Beckman Coulter). Apolipoprotein A1 and apolipoprotein B concentrations were measured using nephelometric methods (Beckman Coulter).

Measurement of LCAT activity

a-LCAT activity was measured by the method of Chen and Albers (17). Briefly: apoAl/phosphatidilcholine/ ${ }^{3} \mathrm{H}$-cholesterol complexes were incubated with plasma in a shaking water bath for 1 hour al $37^{\circ} \mathrm{C}$ (esterification was linear during this time). The reaction was stopped, and lipids were extracted. Esterified and unesterified cholesterol were separated by thin-layer chromatography, and the radioactivity was counted. LCAT specific activity was expressed as the nanograms of cholesterol esterified by $1 \mathrm{~mL}$ of plasma in 1 hour $(\mathrm{nmol} / \mathrm{mL} / \mathrm{h})$.

Measurement of Paroxonase-1 (PON-1) activity (patient 1 and kindred, patient 3)

PON1 activity was measured using phenylacetate as substrate (18). Initial rates of hydrolysis were determined spectrophotometrically at $270 \mathrm{~nm}$. The assay mixture included $1 \mathrm{mM}$ phenylacetate and $0.9 \mathrm{mM} \mathrm{CaCl}_{2}$ in $20 \mathrm{mM}$ Tris- $\mathrm{HCl}, \mathrm{pH} 8.0$, and $10 \mu \mathrm{L}$ serum (diluted 1:40). The $\mathbb{2}_{270}$ for the reaction was $1310 \mathrm{M}^{-}$

${ }^{1} \mathrm{~cm}^{-1}$. Arylesterase activity was expressed as the number of micromoles of phenylacetate hydrolyzed per minute per milliliter of serum. To determine the distribution of PON1 in lipoprotein fractions, $300 \mu \mathrm{L}$ of plasma heparin was separated by size exclusion chromatography using a Bio-Prep SE1000/17 column coupled to a Bio-Rad Duo Flow system as previously described (19) with slight modifications. Briefly, protein elution was accomplished with 2 mM CaCl 2 in 20 $\mathrm{mM}$ Tris- $\mathrm{HCl}, \mathrm{pH} 8.0$, at a flow rate of $1 \mathrm{~mL} / \mathrm{min}$. Fractions of $0.5 \mathrm{~mL}$ were collected and PON1 activity was assessed after elution using $10 \mu \mathrm{L}$ of each fraction. The column was calibrated with VLDL, LDL and HDL isolated by ultracentrifugation from a pool of 5 plasma samples obtained from 5 normolipemic volunteers. For the calibration, cholesterol was determined in the elution fractions by enzymatic colorimetric methods commercially available.

Mutational analysis

Genomic DNA was extracted from peripheral leucocytes using a Commercial Kit (Qiagen). The DNA was amplified using conventional polymerase chain reaction (PCR) to obtain the corresponding exons, including the exon-intron regions. The products of PCR were amplified using primers as follows: $1 F$, CACTCCCACACCAGATAA; 1R TTATGTCGGGGCTTATGC (332 pb) E2-3F, GGGGAGGGTAAGTGTGCTTT; E2-3R, GTGTGCAGGTACCCTGTGG (600 pb) E4-5F, TGTGGAGTACCTGGACAGCA; E4-5R, AGGATCAGCTTGGTCTCACC (584 pb) E6F, GAGCCTACACTCAGCAGGTTG; E6R, GTGGCTGGTGAGGAGTGAA (746 pb). This was carried out under the following conditions: $97^{\circ} \mathrm{C} 7$ min per cycle; $95^{\circ} \mathrm{C} 30 \mathrm{~s} ; 56^{\circ} \mathrm{C} 30 \mathrm{~s} ; 72^{\circ} \mathrm{C} 2$ min; 40 cycles; $72^{\circ} \mathrm{C} 10$ min per cycle; $4^{\circ} \mathrm{C}$ hold. To amplify exon 6 , the temperature for alignment was $58^{\circ} \mathrm{C}$. After purification, all DNA fragments were sequenced using forward and reverse primers. The sequencing was performed in an $\mathrm{ABI}$ prism 3100 genetic analyzer (Applied Biosystems). The reference sequence was obtained from the National Center for Biotechnology Information (NM_000229.1).

Statistical analysis

The distribution of categorical variables is reported as frequencies and percentages. Continuous data is described as mean and standard deviation or with median and interquartile range depending on the parametric or non- parametric distribution of variables. Categorical variables are compared using the chi-

Page 3/21 
square test or Fisher's test as appropriate. Comparisons were carried out with t-test for normally distributed variables and U Mann-Whitney test for nonparametric variables. A p-value $\leq 0.05$ was considered as statistically significant. Statistical analyses were performed using Statistical Package for Social Science (SPSS Inc, Chicago, IL, and Version 21.0) and GraphPad Prism, version 7.0.

\section{Results Of The Systematic Review}

The PRISMA algorithm is shown in Fig. 1. The research strategy retrieved a total of 3,373 publications. After removing any duplicate documents, 2,800 abstracts were reviewed. Of these, 2,153 articles were excluded, as they did not complete inclusion criteria. In total, 87 relevant articles/abstracts were reviewed in detail for eligibility. Of these, six publications were excluded due to incomplete information. Finally, 81 studies were included for the purposes of this article (table 1, (20-101)).

The systematic analysis retrieved 215 cases, of which 71.6\% ( $n=154)$ were FLD, 19.0\% $(n=41)$ were FED and 9.3\% $(n=20)$ were unclassified (table 2). Most of the information was found in case reports (87.6\%). The LCAT deficiency cases are from 33 countries, the majority of individuals are Caucasians and the commonest presenting feature was corneal opacity. There is a predominance of men $(n=116,53.9 \%)$ and the mean age of individuals is $42 \pm 16.5$ years. The median concentration of HDL-C is 7 (4-12) $\mathrm{mg} / \mathrm{dL}$, the median LCAT activity is $1.65(0.0-7.1) \mathrm{nmol} / \mathrm{mL} / \mathrm{hr}$ and median levels of triglycerides are 206 (138$380) \mathrm{mg} / \mathrm{dL}$. A creatinine clearance $<60 \mathrm{~mL} / \mathrm{min}$ was found in $30.2 \%,>60$ in $40.4 \%$ and unknown in the remaining cases. Albuminuria/ proteinuria was present in $39.1 \%$ and absent in $29.8 \%$ of cases. Anemia was reported in $53.9 \%$ and absent in $32.1 \%$. Premature coronary artery disease was present in $7.4 \%$, absent in $59.1 \%$ and not evaluated or unknown in the remaining cases.

On comparing the individuals with FLD and FED, certain differences are apparent. The FLD cases are significantly younger than the FED cases (41 \pm 14.7 vs. $55 \pm 13.8$ years, $P=0.02$, respectively). There was no difference in HDL-C levels between groups. However, LCAT activity was significantly lower in FLD compared to FED $(0.1(0.0-2.1) \mathrm{nmol} / \mathrm{mL} / \mathrm{hr}$ vs. $2.7(0.8-7.0), P=0.01)$. Unsurprisingly, clinical features compatible with FLD are significantly more common in these cases (low creatinine clearance, albuminuria/proteinuria and anemia). Premature coronary artery disease was significantly more prevalent in FED compared with FLD $(P=0.00)$. A comparison between the 3 phenotypes available (unclassified, FLD, and FED) is presented (supplementary table 4). The main characteristics of unclassified patients are also available (supplementary table 5).

Mutational analysis:

A total of 138 mutations in the LCAT gene were recovered (136 in exons and 2 in introns) (supplementary table 1). Mutations have principally been published in Caucasians. Genetic alterations are present on all exons of the gene; there was no association between a particular exon and phenotype. No specific mutation was associated with an ethnic group. The number of mutations associated with FLD, FED and unclassified cases were 77,38 and 23 respectively. The FLD phenotype was associated with exon $6(n=27)$, exon $5(n=13)$ and exon $1(n=13)$. In FED, exon $6(n=12)$, exon $4(n=10)$ and exon $1(n=8)$ appeared to have the greatest number of alterations. In unclassified cases, exon 6 was also the predominant site on the $L C A T$ gene.

The ethnic distribution of the cases was reviewed with respect to location of LCAT mutation (supplementary table 1). Here exon $6(n=41)$ and exon 1 ( $n=19)$ were the most common sites for LCAT mutations. There was a predominance of exon 6 mutations, in particular in Italians, Dutch and Japanese groups. In the Amerindian ethnic group, exon 1 appeared most common in Mexican-Mestizos whilst exon 6 predominated in Brazil and Chile.

Finally, the number of mutations per exon, adjusted for size of exon was examined (supplementary table 2). This avoids exon size bias; exon 6 is more than double the length of the others, perhaps explaining the greater number of mutations encountered. With this analysis, a fairer comparison between exons is possible. Exon 4 and exon 1 show the greatest density of mutations, with exons 5 and 6 showing the least number of alterations. There was no clear relationship between the alterations and the key positions for the enzymatic activity of the LCAT protein.

Characteristics of the Latin American cases:

In total, 48 cases of LCAT deficiency have been published from six Latin American countries (Argentina, Brazil, Chile, Columbia, Ecuador and Mexico) (table 3). There are 38 FLD cases from Brazil (published in an abstract), one unclassified case from Argentina and 3 FLD cases from Chile, Colombia and Ecuador respectively. In Mexico, six cases (4 probands) have been encountered (4 FLD, 1 FED and 1 unclassified); one of which has previously been published (unclassified probable FED).

The mean age of the cases was 45 years (in Brazil it was 38 years) and the cases were equally distributed between genders. The mean HDL-C level was 5.4 (in Brazil it was $<10 \mathrm{mg} / \mathrm{dL}$ ) and LCAT activity was reported in only 4 individuals with a mean level of $3.1 \mathrm{nmol} / \mathrm{mL} / \mathrm{hr}$.

Molecular analysis of the Mexican- Mestizo patients revealed mutations in exon 1 (Trp8*, c.101dupC, c.110C > T) in 3 probands, and a homozygous alteration on exon 4 in 1 proband (c.490C > T). The Chilean case reported alterations on exon 6, c.1210A > G and c.997G > A. In Brazil, 38 cases have been encountered; the investigators report three pathogenic mutations in the LCAT gene, each corresponding to a distinct geographic disease cluster. Two mutations are on exon 6 (c.803 G > A and c.893 C > T) and one on exon 5 (c.679 A > T). Finally, molecular analysis was not carried out in Argentina, Colombia and Ecuador.

\section{MEXICAN PROBANDS WITH LCAT DEFICIENCY SYNDROMES}

\section{PROBAND 1: Familial LCAT deficiency (FLD)}

The proband was a 37-year old woman with bilateral corneal opacities (no deficit in visual acuity). She came from a small village in the state of Oaxaca, in south-west Mexico. She was the 6th of 10 children and her parents were apparently non-consanguineous. Only her paternal grandmother had eyes similar to 
hers. Of her 9 siblings, 2 brothers had corneal opacities and nephrotic syndrome. There was no history of cardiovascular disease in her family. We studied all available members of her family, including her parents and 5 of their 10 children.

She had a history of hyperlipidemia, arterial hypertension and nephrotic syndrome; a renal biopsy reported glomerulopathy characterized by mesangial proliferation, vacuolated macrophages and presence of intramembranous lipid deposits in glomerular capillaries. A recent carotid doppler ultrasound was normal with no alteration in carotid-intima thickness.

Biochemical analysis:

Laboratory results showed a normochromic, normocytic anemia [hemoglobin $9.2 \mathrm{~g} / \mathrm{dL}$ (normal 13-15g/dL)] and measurement of erythrocyte osmotic fragility confirmed the presence of brittle cells. There was evidence of renal failure with nephrotic syndrome (creatinine clearance $47 \mathrm{~mL} / \mathrm{min}$, and proteinuria of $5 \mathrm{~g} / 24 \mathrm{hrs}$ ). The lipid profile showed low HDL-C, hypertriglyceridemia and low levels of apolipoprotein A1 (table 4). The LCAT activity was low (LCAT activity $0.4 \%$, specific activity $3.7 \mathrm{nmol} / \mathrm{mL} / \mathrm{hr})$ and there was a reduction in paroxonase- 1 activity $(27.8 \mathrm{mU} / \mathrm{ml} / \mathrm{h}$, control = $100.77 \mathrm{mU} / \mathrm{ml} / \mathrm{h})$.

Two brothers were affected (homozygotes) and heterozygote family members had half- normal HDL-C concentrations (table 4). All three affected individuals showed some paroxonase-1 activity, whereas LCAT activity was virtually absent. The proband had a $72 \%$ reduction in PON-1 activity, while her affected brothers showed a $47 \%$ and $57 \%$ reduction respectively. The 2 remaining siblings and both parents had low LCAT activity (2.4-3.8\%) and higher paroxonase activity compared to the affected individuals. On separation of the lipoproteins by exclusion chromatography, the paroxonase-1 activity was essentially on HDL, with little activity on LDL.

Mutational analysis:

A novel mutation was encountered in this proband. This was a nucleotide replacement resulting in a stop codon at position 8 on exon 1 of the $L C A T$ gene (in the leader sequence). Tryptophan (TGG) was replaced by Ambar stop (TAG). This is reported as Trp8* or Trp-17* (*indicates stop codon) in the nucleotide sequence. The parents were heterozygous for the mutation and the proband and both her affected brothers were homozygous. The family pedigree is shown in the supplementary Fig. 1.

\section{PROBAND 2: Fish Eye Disease (FED)}

The 70-year-old proband from Mexico City, had bilateral corneal opacities and a history of myocardial infarction. The subject's father and mother had suffered from coronary artery disease (her father died at age 66 , her mother died at age 70 ). The only other family members with similar eyes were her father, paternal grandmother and one male sibling who died soon after birth. None of her 8 siblings were alive. Both her children and 5 grandchildren had normal corneas and no health issues. The proband, her two daughters and 4 of her grandchildren were studied.

The proband had type 2 diabetes mellitus (no known complications), mixed hyperlipidemia, and arterial hypertension (history of atrial fibrillation and left ventricular hypertrophy). The coronary heart disease was characterized by occlusion of 3 coronary vessels (left coronary: trunk, circumflex and right coronary); she had been treated with two medicated stents.

Biochemical analysis:

The lipid profile showed an HDL-C level of $11 \mathrm{mg} / \mathrm{dL}$ (table 4). The remaining laboratory results included; glucose $102 \mathrm{mg} / \mathrm{dL}$, creatinine $0.87 \mathrm{mg} / \mathrm{dL}$, hemoglobin $12.1 \mathrm{~g} / \mathrm{dL}$. The proband had no evidence of anemia or renal disease.

No other family member had a clinical or biochemical phenotype compatible with FED. The proband and her daughters had HDL cholesterol levels $<40 \mathrm{mg} / \mathrm{dL}$, while all the grandchildren had normal HDL-C levels. The proband had low levels of apolipoprotein A1; her daughters had levels intermediate between hers and those of her grandchildren. The proband had extremely low LCAT activity (LCAT specific activity $4.2 \mathrm{nmol} / \mathrm{mL} / \mathrm{hr}$ ) and both daughters had relatively normal LCAT activity (55.0 and $52.7 \mathrm{nmol} / \mathrm{mL} / \mathrm{hr}$ respectively, Control $=78.7)$.

Mutational analysis:

Two mutations were found on exon 1:

1. On one allele, there was an insertion of cysteine (reported as c.101dupC) at codon 34. This mutation resulted in a stop codon 7 codons later. The proband was heterozygote for this mutation.

2. On the other allele, the alteration was c.110C > T. When this allele is translated, threonine is substituted by methionine (ACG-ATG Thr37Met) (missense mutation) at position 37 of the protein. The proband was heterozygote for this mutation.

The proband is compound heterozygote for both mutations. Daughter 1 is heterozygote for the second mutation (c.110 C > T at codon 37), while daughter 2 is heterozygote for the first mutation (c.101dupC at codon 34). Analysis of the apoA1 gene and its promotor region was also carried out in the proband, no alterations were found.

The family pedigree is shown in supplementary Fig. 1.

3. PROBAND 3 (Familial LCAT Deficiency). 
The proband was a 29-year-old woman from Monterrey, with bilateral corneal opacities resembling premature corneal arcus. She had an FLD phenotype with extremely low levels of HDL-C, anemia and kidney disease (glomerulopathy). There was no clinical or biochemical evidence of FLD or FED in her parents or sibling. There was no family history of premature cardiovascular disease. She had attended consultations with several specialists, had undergone three kidney biopsies and one bone marrow aspiration; despite this she had not been diagnosed.

Biochemical analysis.

The proband had an HDL-C level of 4mg/dL (table 4). The laboratory profile showed: glucose $101 \mathrm{mg} / \mathrm{dL}$, creatinine $1.12 \mathrm{mg} / \mathrm{dL}$, hemoglobin $12.9 \mathrm{~g} / \mathrm{dL}$ and $24-$ hour urinary protein $2307 \mathrm{mg} /$ day. The proband had extremely low LCAT activity $(7.3 \mathrm{nmol} / \mathrm{mL} / \mathrm{hr}$, LCAT specific activity in control 145.34nmol/mL/hr) and a $60 \%$ reduction in PON-1 activity compared with controls.

Mutational analysis:

The genetic alteration was a point mutation in exon 4 of the LCAT gene, i.e., a G to A substitution on codon 140 converting Arginine to Histidine. The family pedigree is shown in supplementary Fig. 1.

\section{Discussion}

FLD and FED are rare LCAT deficiency syndromes with differing clinical manifestations. This article discusses the results of the first systematic analysis evaluating the ethnic distribution of LCAT deficiency, with particular emphasis on Latin America, presenting the case histories of three Mexican-Mestizo probands.

The systematic review retrieved 215 published cases of which $71.6 \%$ were reported as FLD, $19 \%$ as FED and $9.4 \%$ were unclassified. This number is significantly greater than that reported in the current literature (102). The majority of probands have been published in case reports, often with incomplete clinical or genetic information. It is evident that this disease continues to be encountered at a late age, with corneal opacifications being the principal reason for consultation. Furthermore, FED is diagnosed significantly later than FLD, probably due to the more severe clinical phenotype of the later warranting earlier medical attention.

The biochemical features of the cases showed that LCAT enzyme activity was significantly lower in FLD compared to FED. Low HDL cholesterol levels are a characteristic feature of this disease, however, there was no difference in concentrations between the phenotypes. Indeed, FLD and FED can have similar lipid profiles, suggesting any variability in parameters is unrelated to LCAT function. Pavanello et al. have commented that the severity of the hypoalphalipoproteinemia varies widely among carriers of different LCAT genotypes (102). Furthermore, carriers of one mutant LCAT allele show an intermediate biochemical phenotype between homozygous carriers and controls, suggesting that the disease, which is reported as recessive, is indeed codominant for the biochemical phenotype. This was also confirmed in the relatives of the Mexican-Mestizo probands.

The clinical features of the cases showed a clear difference between FED and FLD, with renal disease and anemia prevalent in the later. Renal damage is the principle cause of morbidity and mortality in patients with FLD; however, the rate at which damage occurs is variable. It usually begins as proteinuria in childhood and progresses to renal failure in the fourth decade, requiring dialysis therapy or renal transplantation. It is suggested that the deposition and accumulation of nephrotoxic and pro-inflammatory lipoprotein X (Lp-X) particles, mainly in the mesangium, in the absence of LCAT, may explain the development of renal disease (14). LpX may serve as a biomarker for monitoring recombinant LCAT therapy in the future. However, not all cases of FLD showed significant proteinuria or reduced eGFR; this suggests that the rate of progression to renal failure may be highly variable. Lamiquiz-Moneo et al. state that this clinical variability is likely to be related to the biochemical /lipid phenotype rather than to the inherited mutation (81). In addition, 9.3\% of cases had an unclassified clinical phenotype; the authors could not confirm either familial LCAT deficiency (FLD) or fish eye disease (FED) (supplementary tables 4 and 5). Some authors have commented that the clinical manifestations of patients with LCAT gene mutations may vary even among members of the same family carrying identical mutations (42). Therefore, it is evident that LCAT deficiency syndromes show both biochemical and clinical heterogeneity. Mahapatra et al., have reported the co-existence of differing phenotypes in the same family; they discuss the case of a proband with FLD, while his sister and mother presented with FED, despite belonging to the same family and probably having the same mutation. Hence, the clinical presentation and biochemical studies showed important phenotypic variability (https://www.ncbi.nlm.nih.gov/pmc/articles/PMC4663774/\#_ffn_sectitle) (90).

An important finding of this systematic review was the significantly greater prevalence of premature CHD in FED patients compared to FLD patients. The cardiovascular risk associated with LCAT deficiency syndromes has been a matter of debate for a number of years. A severe deficiency of HDL-C in LCAT deficient carriers would be expected to increase their risk of developing coronary heart disease (84). Oldoni et al., have compared carotid intima media thickness between 33 heterozygous FLD subjects and 41 heterozygous FED subjects (103). Carriers of FLD mutations exhibited less carotid atherosclerosis, whereas those with FED mutations presented with more subclinical atherosclerosis. The authors proposed that this discrepancy was related to the capacity of LCAT to esterify cholesterol on apolipoprotein B-containing lipoproteins- this capacity is lost in FLD, but is unaffected in FED. In a study of Italian FLD families, the inheritance of a mutated LCAT genotype had a remarkable gene-dose dependent effect in reducing carotid IMT, whereas a subgroup of these carriers also showed normal flow-mediated dilation $(66,84)$. However, we must acknowledge that generally there are few longitudinal follow-up studies of these patients hence, a definitive conclusion has not been reached.

The molecular defects associated with LCAT deficiency syndromes show heterogeneity. In total, 138 LCAT mutations were encountered with no particular exon dominating in a particular ethnicity. There was no association between clinical phenotype and genetic alteration, this may be due to the low number of cases worldwide. Exon 6 was the predominant site for both FLD and FED; however, after adjusting for exon size, exon 1 and 4 showed the greatest concentration of mutations. At present, it is impossible to predict the phenotype (FLD or FED) associated with the LCAT mutations (102). 
With regards to ethnicity, at least 33 different groups are represented, of which Caucasians are most common. The predominance of Caucasian and Asian cases may reflect better health awareness and access to health care compared with developing regions. Remarkably, only one case has been found in the African sub-continent. Cases are more likely to be found in affluent countries, but also in countries hosting research groups with interest and resources to investigate this disease. In Latin American few cases have been published (83-89). At present, only six countries have reported probands with LCAT deficiency, and genetic evaluation has only been carried out in three countries. Of these, Brazil reports three mutations causing FLD each associated with a distinct geographical region. In Mexico, the first FLD proband, came from an isolated village in the south of Mexico, there is little genetic admixture in this region. The indigenous heritage of this patient may have been responsible for disease susceptibility. The mutations reported in Brazil and Chile are on exon 5 and 6. In Mexico, exon 1 mutations predominate (3 probands), with only 1 case from the north of the country showing a homozygous exon 4 alteration.

The first Mexican- Mestizo proband (FLD phenotype) showed an alteration located in the leader sequence (a stop codon at position 8 in exon 1 of the LCAT gene), thus normal protein synthesis is abolished. In accordance with the genetic results, the laboratory results confirmed low HDL-C concentrations and very low specific LCAT activity. Both parents and 2 siblings were heterozygotes and presented with intermediate low HDL-C levels ( $<40 \mathrm{mg} / \mathrm{dL}$ ) and low specific LCAT activity (22-36\%). To our knowledge, this particular mutation is novel, only one other mutation in this region of the gene has been reported: Calabresi et al. mention a subject with a Thr-13Met mutation and an FLD phenotype (65).

One interesting finding was that the proband continued to show paroxonase- 1 activity. This was essentially on HDL, even though the number of particles was extremely low and despite a clear lack of LCAT activity. The proband had $27 \%$ activity, while her affected siblings had approximately $50 \%$ activity. The heterozygote family members had essentially normal PON-1 activity. This enzyme prevents the conversion of LDL into a more atherogenic particle (106). Preserved PON-1 activity has been reported in other HDL-C deficiency states, and in vitro experiments with LCAT deficient plasma suggest an apparent maintenance of cholesterol efflux $(95,107,108)$. Reverse cholesterol transport and protection of LDL from oxidative stress, is possibly conserved in complete LCAT deficiency, supporting the differential cardiovascular risk between phenotypes.

The second Mexican- Mestizo proband (FED) had two distinct $L C A T$ mutations, one on each allele (compound heterozygote). One of the alterations was a frameshift mutation (c.101dupC) on exon 1; the other mutation was a missense mutation (c.110C > T) on the same exon. Both mutations have previously been reported in the literature $(26,27,28)$.

Argyropoulos et al. have reported an FLD Caucasian proband who was compound heterozygote with a missense mutation identical to that in the proband (c.110C > T on exon 1) (45). Posadas-Sanchez et al. have reported the presence of the same missense mutation (c.110C > T) on both alleles (homozygote) in an unrelated Mexican subject with an unclassified LCAT deficiency syndrome (probable FED) (89). The 34-year old Mexican man had type 2 diabetes, premature coronary artery disease, corneal opacities, normal renal function and extremely low levels of HDL cholesterol (2mg/dL). The investigators reported an increase in the number of small HDL particles in the proband. In addition, the HDL particles had a reduced ability to promote cholesterol efflux (PON-1 activity was low). Finally, Bujo et al. have published the presence of the homozygous c.101dupC mutation on exon 1 in a Japanese subject. This resulted in a truncated 16 amino-acid non -functional LCAT protein and an FLD phenotype (21).

Predicting the effect of the co-existence of these mutations (one on each allele) on LCAT function and structure is not straightforward. The majority of mutations are not located in sites involved in the catalytic function of the enzyme; the affected sites are probably involved in maintaining protein stability and structure. The mature LCAT protein contains 416 amino acids and a leader sequence $(67 \mathrm{kDa})(109,110)$. The enzyme is thought to undergo post-translational glycosylation which appears to be essential for the conformational stability of the protein (111). In addition, LCAT has two disulfide bridges between Cyst50Cys74 and Cys313-Cys356; the first bridge partially covers the active site of LCAT, forms part of the lid region and is thought to enable the enzyme to bind to lipid surfaces. Hence, in this patient, the genetic alterations may interfere with the nearby lid structure or produce a conformational change when the mature protein is folded, resulting in enzyme- substrate interference. The frameshift mutation is a more detrimental alteration; however, clinical expression of which would only be apparent in homozygotes. Hence, the predominant phenotype in the subject is FED.

The third Mexican-Mestizo proband (FLD), had a point mutation on exon 4 of the $L C A T$ gene, i.e., a $\mathrm{G}$ to $\mathrm{A}$ substitution on codon 140 converting Arginine to Histidine. This mutation has been reported previously in an Austrian kindred who were also homozygous for this modification (38). It appears that this domain (where Arg140 resides) is crucial for an enzymatically active LCAT protein, mutations in this region possibly affect tertiary structure.

In Latin America, persons with LCAT deficiency syndromes face unique challenges. The medical community is unaware of this condition; the third proband had attended consultations with several specialists, had undergone three kidney biopsies and one bone marrow aspiration; despite this, she had not been diagnosed. Additionally, many centers do not have the infrastructure to carry out the biochemical or genetic studies necessary to confirm this condition. Current management of FLD is preventative and involves lipid lowering therapy, ACE inhibitors, diuretics and steroids, in order to delay progression to endstage renal disease: for many in Latin America, these medications will be an out of pocket expense. Furthermore, in this region, access to further treatment with peritoneal dialysis or hemodialysis is variable. This is related to fragmented health care coverage and socioeconomic inequality. Although, provision of renal replacement therapy (RRT) has increased in all Latin American countries over the past 20 years, universal access is available in only a few countries (Argentina, Brazil, Chile, Cuba, Uruguay, Venezuela, and Colombia) (112). Kidney transplantation may offer a temporary cure, but reoccurrence of nephropathy is inevitable and occurs within a few years (113). Currently, trials are underway with human recombinant LCAT enzyme and there is the possibility of gene therapy in the future (114). However, such products maybe subsequently unavailable and/or unaffordable (cost is much greater than average monthly income) to most of the Latin American population (115).

Earlier identification and adequate follow up of patients is urgently needed; the implementation of models of care and national disease registries can aid in this process. Recently, the Norwegian National Advisory Unit on Rare Disorders has been asked to establish a worldwide contact registry on FLD; this will allow the integration of efforts throughout the world to tackle the health burden and improve care for this condition (84). 
STUDY STRENGTHS AND LIMITATIONS The strengths of this study include that this is the first systematic review of LCAT deficiency syndromes evaluating the ethnic distribution of this condition. This work highlights the major knowledge gaps in this disease. Limitations include the lack of standardized data in the case reports. This limited the analysis in the systematic review. In addition, the lack of longitudinal data does not allow the natural history of this disease to be examined adequately. Measurements of free cholesterol and cholesteryl ester, as well as cholesterol esterification rate to complete the biochemical characterization of the Mexican probands and their families would have been desirable.

\section{Conclusion}

In conclusion, the systematic review shows that LCAT deficiency syndromes are diagnosed late; with FLD cases identified significantly earlier than FED. This review confirms that this condition is clinically and genetically heterogeneous. There was no association between ethnicity and LCAT mutations. However, there was a significantly greater risk of premature coronary artery disease in FED compared to FLD. This finding is clinically important, it suggests that management should be tailored according to the LCAT deficiency profile. In FLD patients, the priority is to mitigate both CVD and progression to end stage

kidney disease; in contrast, in FED patients, management of cardiovascular risk may well be paramount. Finally, the LCAT mutations discussed in this article are the only ones reported in the Mexican- Amerindian population. The novel mutation associated with FLD in a Mexico-Mestizo woman, may suggest the influence of Amerindian ancestry.

\section{Abbreviations}

TC= total cholesterol, PON-1= paroxonase-1, FLD: familial LCAT deficiency, FED: Fish Eye disease, LCAT: Lecithin-cholesterol acyltransferase, HDL: high density lipoproteins, LDL: Iow density lipoprotein, VLDL: very low density lipoprotein, apo A-I: apolipoprotein A-I, apo A-II: apolipoprotein A-II,

\section{Declarations}

\section{Ethics approval and consent to participate:}

this study received approval from the Research and Ethics Committee at Instituto Nacional de Ciencias Médicas y Nutrición Salvador Zubirán.

\section{Consent for publication:}

not applicable

\section{Availability of data and materials:}

all data generated or analyzed during this study are included in this published article [and its supplementary information files].

\section{Competing interests:}

authors do not have any conflicts of interest to disclose in relation to this manuscript.

\section{Funding:}

no funding was received for this work.

\section{Authors' contributions:}

RM, DEL, AJM: conceptualization, methodology, research, analysis, writing, review and edition of the manuscript. OAPM, MLOS, YS: research, analysis, review and edition of the manuscript. MTT, CAAS: conceptualization, methodology, supervision, project administration, funding acquisition, review and edition of the manuscript. All authors read and approved the final manuscript.

\section{Acknowledgements:}

not applicable

\section{References}

1. Rousset, X., R. Shamburek, B. Vaisman, M. Amar and A.T. Remaley. 2011. Lecithin cholesterol acyltransferase? An anti or pro atherogenic factor? Current Atheroscler Rep. 13:249-256.

2. Savel, J., M. Lafitte, Y. Pucheu, V. Pradeau, A. Tabarin, and T. Couffinhal. 2012. Very low levels of HDL cholesterol and atherosclerosis, a variable relationship - a review of LCAT deficiency. Vasc Health and Risk Manag. 8:357-361.

3. Razavi AE, Ani M, Pourfarzam M, and Naderi GA. Associations between high density lipoprotein mean particle size and serum paraoxonase-1 activity. J Res Med Sci. 2012 Nov; 17(11): 1020-1026

4. Santamarina-Fojo, S., G. Lambert, J.M. Hoeg, and H.B. Jr. Brewer. 2000. Lecithin-cholesterol acyltransferase: role in lipoprotein metabolism, reverse cholesterol transport and atherosclerosis. Curr Opin Lipidol. 11:267-275.

5. Peelman, F., J. Vandekerckhove, and M. Rosseneu. 2000. Structure and function of lecithin cholesterol acyl transferase: new insights from structural predictions and animal models. Curr Opin Lipidol 11:155-160. 
6. Holleboom, A.G., J.A. Kuivenhoven, F. Peelman, A.W. Schimmel, J. Peter, J.C. Defesche, J.J. Kastelein, G.K. Hovingh, E.S. Stroes, and M.M. Motazacker. 2011. High Prevalence of Mutations in LCAT in Patients with Low HDL Cholesterol Levels in The Netherlands: Identification and Characterization of Eight Novel Mutations. Hum Mutat. 32:1290-1298.

7. Miettinen, H.E., H. Gylling, J. Tenhunen, J. Virtamo, M. Jauhiainen, J. K. Huttunen, I. Kantola, T.A. Miettinen, and K. Kontula. 1998. Molecular genetic study of Finns with hypoalphalipoproteinemia and hyperalphalipoproteinemia: a novel Gly230 Arg mutation (LCAT [Fin]) of lecithin: cholesterol acyltransferase (LCAT) accounts for $5 \%$ of cases with very low serum HDL cholesterol levels. Arterioscler Thromb Vasc Biol. 18:591-598.

8. Kiss, R.S., N. Kavaslar, K. Okuhira, M.W. Freeman, S. Walter, R.W. Milne, R. McPherson, and Y. L. Marcel. 2007. Genetic etiology of isolated low HDL syndrome: incidence and heterogeneity of efflux defects. Arterioscler Thromb Vasc Biol. 27:1139-1145.

9. Santamarina-Fojo, S., J. Hoeg, G. Assmann, and H.B. Jr. Brewer. 2008. Chapter 118: Lecithin cholesterol acyltransferase deficiency and fish eye disease. In The Online Metabolic \& Molecular Bases of Inherited Disease. D. Valle, A.L. Beaudet, B. Vogelstein, K.W. Kinzler, S.E. Antonarakis, and A. Ballabio, editors. McGraw-Hill, New York, NY.

10. McIntyre, N. 1988. Familial LCAT deficiency and fish-eye disease. J Inherit Metab Dis. 11:45-46

11. Calabresi, L., and G. Franceschini. 2010. Genetic LCAT Deficiency: Molecular Diagnosis, Plasma Lipids, and Atherosclerosis. In High Density Lipoproteins, Dyslipidemia, and Coronary Heart Disease. E.J. Schaefer, editor. Springer, New York, NY. 89-93

12. Santamarina-Fojo, S., J.M. Hoeg, G. Assmann, and H.B. Jr. Brewer. 2001. Lecithin cholesterol acyltransferase deficiency and fish eye disease. In The Metabolic and Molecular Bases of Inherited Diseases. C.R. Scriver, A.L Beaudet, W.S. Sly, and D. Valle, editors. McGraw-Hill, New York, NY. $2817-2833$.

13. Calabresi L, A. Ossoli, and G. Fanceschini. 2014. Lecithin:CholesterolAcyltransferase (LCAT) Deficiency: Molecular Genetics. In eLS. John Wiley \& Sons Ltd. Chichester, UK.

14. Saeedi, R., M. Li, and J. Frohlich. 2015. A review on lecithin: cholesterol acyltransferase deficiency. Clin Biochem. 48:472-475

15. Rivas-Gomez B, Almeda-Valdés P, Tussié-Luna MT and Aguilar-Salinas CA. Dyslipidemia in Mexico, a Call for Action. Rev Invest Clin. 2018;70:211-6

16. Aguilar-Salinas CA, Canizales-Quinteros S, Rojas-Martínez R, Mehta R, Rodriguez-Guillén R, Ordoñez-Sanchez ML, Riba L, Tusié-Luna MT. The NonSynonymous Arg230Cys Variant (R230C) of the ATP-binding Cassette Transporter A1 Is Associated With Low HDL Cholesterol Concentrations in Mexican Adults: A Population Based Nation Wide Study. Atherosclerosis 2011 May;216(1):146-50

17. Chen, C.H., and J.J. Albers. 1982. Characterization of proteoliposomes containing apoprotein A-I. A new substrate for the measurement of lecithin cholesterol acyltransferase activity. J. Lipid Res. 23:680-691

18. Gann K.N., A. Smolen, H.W. Eckerson, and B.N. La Du. 1991. Protein purification of human serum paraoxonase/arylesterase. Evidence for one esterase catalyzing both activities. Drug Metab Dispos. 19:100-106

19. Carreón-Torres, E., K. Rendón-Sauer, M. Monter-Garrido, P. Toledo-lbelles, R. Gamboa, M. Menjivar, R. López-Marure, G. Luc, C. Fievet, D. Cruz, G. VargasAlarcón, and O. Pérez-Méndez. 2009. Rosiglitazone modifies HDL structure and increases HDL-apo Al synthesis and catabolic rates. Clin Chim Acta; 401:37-41

20. Okubo, M., Y. Aoyama, H. Shio, J.J. Albers, and T. Murase. 1996. A novel missense mutation (Asn5->lle) in lecithin: cholesterol acyltransferase (LCAT) gene in a Japanese patient with LCAT deficiency. Int J Clin Lab Res. 26:250-254.

21. Bujo, H., J. Kusunoki, M. Ogasawara, T. Yamamoto, Y. Ohta, T. Shimada, Y. Saito, and S. Yoshida. 1991. Molecular defect in familial lecithin:cholesterol acyltransferase (LCAT) deficiency: a single nucleotide insertion in LCAT gene causes a complete deficient type of the disease. Biochem Biophys Res Commun. 181:933-940.

22. Miida, T., B. Zhang, K. Obayashi, U. Seino, Y. Zhu, T. Ito, Y. Nakamura, M. Okada, and K. Saku. 2004. T13M mutation of lecithin-cholesterol acyltransferase gene causes fish-eye disease. Clin Chim Acta. 343:201-208.

23. Yang, X., A. Inazu, A. Honjo, I. Koizumi, K. Kajinami, J. Koizumi, S. Marcovina, J. Albers, and H. Mabuchi. 1997. Catalytically inactive lecithin: cholesterol acyltransferase (LCAT) caused by a Gly 30 to Ser mutation in a family with LCAT deficiency. J. Lipid Res. 38: 585-591.

24. Naito, S., M. Kamata, M, Furuya, M. Hayashi, M. Kuroda, H. Bujo, and K. Kamata. 2013. Amelioration of circulating lipoprotein profile and proteinuria in a patient with LCAT deficiency due to a novel mutation (Cys74Tyr) in the lid region of LCAT under a fat-restricted diet and ARB treatment. Atherosclerosis. 228:193-197.

25. Katayama, A., J. Wada, H.U. Kataoka, H. Yamasaki, S. Teshigawara, T. Terami, K. Inoue, M. Kanzaki, K. Murakami, A. Nakatsuka, H. Sugiyama, N. Koide, H. Buho, and H. Makino. 2011. Two novel mutations of lecithin:cholesterol acyltransferase (LCAT) gene and the influence of APOE genotypes on clinical manifestations. NDT Plus. 4:299-302.

26. Gotoda, T., N. Yamada, T. Murase, M. Sakuma, N. Murayama, H. Shimano, K. Kozaki, J.J. Albers, Y. Yazaki, and Y. Akanuma. 1991. Differential phenotypic expression by three mutant alleles in familial lecithin: cholesterol acyltransferase deficiency. Lancet. 338:778-781.

27. Tsuchiya, Y., Y. Ubara, R. Hiramatsu, T. Suwabe, J. Hoshino, K. Sumida, E. Hasegawa, M. Yamanouchi, N. Hayami, Y. Marui, N. Sawa, S. Hara, K. Takaichi, and K. Oohashi. 2011. A case of familial lecithin-cholesterol acyltransferase deficiency on hemodialysis for over 20 years. Clin Nephrol. 76:492-498.

28. Hirashio, S., K. Izumi, T. Ueno, T. Arakawa, T. Naito, T. Taguchi, and N. Yarioka. 2010. Point mutation (C to T) of the LCAT gene resulting in A140C substitution. J Atheroscler Thromb. 17:1297-1301.

29. Wang, X.L., J. Osuga, F. Tazoe, K. Okada, S. Nagashima, M. Takahashi, T. Ohshiro, T. Bayasgalan, H. Yagyu, K. Okada, and S. Ishibashi. 2011. Molecular analysis of a novel LCAT mutation (Gly179 $\rightarrow$ Arg) found in a patient with complete LCAT deficiency. J Atheroscler Thromb. 18:713-719.

30. Maruyama, T., S. Yamashita, Y. Matsuzawa, H. Bujo, K. Takahashi, Y. Saito, S. Ishibashi, K. Ohashi, F. Shionoiri, T. Gotoda, N. Yamada, and T. Kita; Research Committee on Primary Hyperlipidemia of the Ministry of Health and Welfare of Japan_2004. Mutations in Japanese subjects with primary hyperlipidemia-results from the Research Committee of the Ministry of Health and Welfare of Japan since 1996. J Atheroscler Thromb. 11:131-145.

Page 9/21 
31. Moriyama K ${ }^{1}$, Sasaki J, Arakawa F, Takami N, Maeda E, Matsunaga A, Takada Y, Midorikawa K, Yanase T, Yoshino G. 1995. Two novel point mutations in the lecithin:cholesterol acyltransferase (LCAT) gene resulting in LCAT deficiency: LCAT (G873 deletion) and LCAT (Gly344->Ser). J Lipid Res. 36(11):232943.

32. Maeda E, Naka Y, Matozaki T, Sakuma M, Akanuma Y, Yoshino G, Kasuga M.1991. Lecithin-cholesterol acyltransferase (LCAT) deficiency with a missense mutation in exon 6 of the LCAT gene. Biochem Biophys Res Commun.31;178(2):460-6.

33. Kanai M. Clinical Features and Visual Function in a Patient With Fish-eye Disease: Quantitative Measurements and Optical Coherence Tomography. Am J Ophthalmol Case Rep 2018 Feb 24;10:137-141.

34. Park, C.W., M.H. Lim, D.Y. Youn, S.E. Jung, S. Chung, Y.S. Ahn, Y.S. Chang, and J.H. Lee. 2009. Two novel frame shift mutations in lecithin:cholesterol acyltransferase (LCAT) gene associated with a familial LCAT deficiency phenotype. Atherosclerosis. 206:346-348.

35. Holleboom, A.G., J.A. Kuivenhoven, C.C. van Olden, J. Peter, A.W. Schimmel, J.H. Levels, R.M. Valentijn, P. Vos, J.C. Defesche, J.J. Kastelein, G.K. Hovingh, E.S. Stroes, and C.E. Hollak. 2011. Proteinuria in early childhood due to familial LCAT deficiency caused by loss of a disulfide bond in lecithin:cholesterol acyl transferase. Atherosclerosis. 216:161-165.

36. Contacos, C., D.R. Sullivan, K.A. Rye, H. Funke, and G. Assmann. 1996. A new molecular defect in the lecithin: cholesterol acyltransferase (LCAT) gene associated with fish eye disease. J Lipid Res. 37:35-44.

37. Hörl, G., P.M. Kroisel, E. Wagner, B. Tiran, E. Petek, and E. Steyrer. 2006. Compound heterozygosity (G71R/R140H) in the lecithin:cholesterol acyltransferase (LCAT) gene results in an intermediate phenotype between LCAT-deficiency and fish-eye disease. Atherosclerosis. 187:101-109.

38. Steyrer, E., S. Haubenwallner, G. Hörl, W. Giessauf, G.M. Kostner, and R. Zechner. 1995. A single G to A nucleotide transition in exon IV of the lecithin: cholesterol acyltransferase (LCAT) gene results in an Arg140 to His substitution and causes LCAT-deficiency. Hum Genet. 96:105-9.

39. Wiebusch, H., P. Cullen, J.S. Owen, D. Collins, P.S. Sharp, H. Funke, and G. Assmann. 1995. Deficiency of lecithin:cholesterol acyltransferase due to compound heterozygosity of two novel mutations (Gly33Arg and 30 bp ins) in the LCAT gene. Hum Mol Genet. 4:143-145.

40. Winder, A.F., J.S. Owen, P.H. Pritchard, D. Lloyd-Jones, D.T. Vallance, P. White, and R. Wray. 1999. A first British case of fish-eye disease presenting at age 75 years: a double heterozygote for defined and new mutations affecting LCAT structure and expression. J Clin Pathol. 52:228-230.

41. Rader, D.J., K. Ikewaki, N. Duverger, H. Schmidt, H. Pritchard, J. Frohlich, M. Clerc, M.F. Dumon, T. Fairwell, and L. Zach. 1994. Markedly accelerated catabolism of apolipoprotein A-II (ApoA-II) and high density lipoproteins containing ApoA-II in classic lecithin: cholesterol acyltransferase deficiency and fish-eye disease. J Clin Invest. 93:321-330.

42. Funke, H., A. von Eckardstein, P.H. Pritchard, A.E. Hornby, H. Wiebusch, C. Motti, M.R. Hayden, C. Dachet, B. Jacotot, and U. Gerdes. 1993. Genetic and phenotypic heterogeneity in familial lecithin: cholesterol acyltransferase (LCAT) deficiency. Six newly identified defective alleles further contribute to the structural heterogeneity in this disease. J Clin Invest. 91:677-683.

43. Weber $\mathrm{CL}^{1}$, Frohlich J, Wang J, Hegele RA, Chan-Yan C. 2007. Stability of lipids on peritoneal dialysis in a patient with familial LCAT deficiency. Nephrol Dial Transplant. Jul;22:2084-2088.

44. Nanjee, M.N., J. Stocks, C.J. Cooke, H.O. Molhuizen, S. Marcovina, D. Crook, J.P. Kastelein, and N.E. Miller. 2003. A novel LCAT mutation (Phe382->Val) in akindred with familial LCAT deficiency and defective apolipoprotein B-100. Atherosclerosis. 170:105-113.

45. Argyropoulos, G., A. Jenkins, R.L. Klein, T. Lyons, B. Wagenhorst, J. St Armand, S.M. Marcovina, J.J. Albers, P.H. Pritchard, and W.T. Garvey. 1998. Transmission of two novel mutations in a pedigree with familial lecithin:cholesterol acyltransferase deficiency: structure-function relationships and studies in a compound heterozygous proband. J Lipid Res. 39:1870-1876.

46. Kuivenhoven, J.A., A.F. Stalenhoef, J.S. Hill, P.N. Demacker, A. Errami, J.J. Kastelein, and P.H. Pritchard. 1996. Two novel molecular defects in the LCAT gene are associated with fish eye disease. Arterioscler Thromb Vasc Biol. 16:294-303.

47. Holleboom, A.G., J.A. Kuivenhoven, F. Peelman, A.W. Schimmel, J. Peter, J.C. Defesche, J.J. Kastelein, G.K. Hovingh, E.S. Stroes, and M.M. Motazacker. 2011. High prevalence of mutations in LCAT in patients with low HDL cholesterol levels in The Netherlands: identification and characterization of eight novel mutations. Hum Mutat. 32:1290-1298.

48. Kuivenhoven, J.A., H. Weibusch, P.H. Pritchard, H. Funke, R. Benne, G. Assmann, and J.J. Kastelein. 1996. An intronic mutation in a lariat branchpoint sequence is a direct cause of an inherited human disorder (fish-eye disease). J Clin Invest. 98:358-364.

49. Kuivenhoven, J.A., H. Pritchard, J. Hill, J. Frohlich, G. Assmann, and J. Kastelein. 1997. The molecular pathology of lecithin:cholesterol acyltransferase (LCAT) deficiency syndromes. J Lipid Res. 38:191-205.

50. Kuivenhoven, J.A., E.J. van Voorst tot Voorst, H. Wiebusch, S.M. Marcovina, H. Funke, G. Assmann, P.H. Pritchard, and J.J. Kastelein. 1995. A unique genetic and biochemical presentation of fish-eye disease. J Clin Invest. 96:2783-2791.

51. Miettinen, H.E., H. Gylling, J. Tenhunen, J. Virtamo, M. Jauhiainen, J.K. Huttunen, I. Kantola, T.A. Miettinen, and K. Kontula. 1998. Molecular genetic study of Finns with hypoalphalipoproteinemia and hyperalphalipoproteinemia: a novel Gly230 Arg mutation (LCAT [Fin]) of lecithin:cholesterol acyltransferase (LCAT) accounts for 5\% of cases with very low serum HDL cholesterol levels. Arterioscler Thromb Vasc Biol. 18:591-598.

52. Gylling, H., and T. A. Miettinen. 1992. Non-cholesterol sterols, absorption and synthesis of cholesterol and apolipoprotein A-I kinetics in a Finnish lecithincholesterol acyltransferase deficient family. Atherosclerosis 95: 25-33.

53. Miettinen, H., H. Gylling, I. Ulmanen, T. A. Miettinen, and K. Kontula. 1995. Two different allelic mutations in a Finnish family with lecithin:cholesterol acyltransferase deficiency. Arteriosclerosis, thrombosis, and vascular biology 15: 460-467.

54. Teh, E.M., J.W. Chisholm, P.J. Dolphin, Y. Pouliquen, M. Savoldelli, J.L de Gennes, and P. Benlian. 1999. Classical LCAT deficiency resulting from a novel homozygous dinucleotide deletion in exon 4 of the human lecithin: cholesterol acyltransferase gene causing a frameshift and stop codon at residue 144 . Atherosclerosis. 146:141-151.

Page $10 / 21$ 
55. Klein HG, Santamarina-Fojo S, Duverger N, Clerc M, Dumon MF, Albers JJ, Marcovina S, Brewer HB Jr. 1993 Fish eye syndrome: a molecular defect in the lecithin-cholesterol acyltransferase (LCAT) gene associated with normal alpha-LCAT-specific activity. Implications for classification and prognosis. J Clin Invest. $92: 479-85$.

56. Guerin, M., C. Dachet, S. Goulinet, D. Chevet, P.J. Dolphin, M.J. Chapman, and M. Rouis. 1997. Familial lecithin:cholesterol acyltransferase deficiency: molecular analysis of a compound heterozygote: LCAT (Arg147 $\rightarrow$ Trp) and LCAT (Tyr171 $\rightarrow$ Stop). Atherosclerosis. 131:85-95.

57. Elkhalil L, Majd Z, Bakir R, Perez-Mendez O, Castro G, Poulain P, Lacroix B, Duhal N, Fruchart JC, Luc G. 1997. Fish-eye disease: structural and in vivo metabolic abnormalities of high-density lipoproteins. Metabolism. 46 (5):474-83.

58. Dorval I, Jezequel P, Dubourg C, Chauvel B, Le Pogamp P, Le Gall JY. 1994. Identification of the homozygous missense mutation in the lecithin:cholesterol-acyltransferase (LCAT) gene, causing LCAT familial deficiency in two French patients. Atherosclerosis. 105(2):251-2.

59. Baass, A., H. Wassef, M. Tremblay, L. Bernier, R. Dufour, and J. Davignon. 2009. Characterization of a new LCAT mutation causing familial LCAT deficiency (FLD) and the role of APOE as a modifier gene of the FLD phenotype. Atherosclerosis. 207:452-457.

60. Funke, H., A. Von Eckardstein, P.H. Pritchard, J.J. Albers, J.J. Kastelein, C. Droste, and G. Assmann. 1991. A molecular defect causing fish eye disease: an amino acid exchange in lecithin-cholesterol acyltransferase (LCAT) leads to the selective loss of alpha-LCAT activity. Proc Natl Acad Sci U S A. 88:48554859.

61. Klein, H.G., P. Lohse, P.H. Pritchard, D. Bojanovski, H. Schmidt, and H.B. Jr. Brewer. 1992. Two different allelic mutations in the lecithin-cholesterol acyltransferase gene associated with the fish eye syndrome. Lecithin-cholesterol acyltransferase (Thr123---lle) and lecithin-cholesterol acyltransferase (Thr347-Met). J Clin Invest. 89:499-506.

62. Bender, B.U., T. Quaschning, H.P. Neumann, D. Schmidt, and A. Kraemer-Guth. 2007. A novel frameshift mutation of the lecithin:cholesterol acyltransferase (LCAT) gene associated with renal failure in familial LCAT deficiency. Clin Chem Lab Med. 45:483-486.

63. Owen, J.S., H. Wiebusch, P. Cullen, G.F. Watts, V.L. Lima, H. Funke, and G. Assmann. 1996. Complete Deficiency of Plasma Lecithin-Cholesterol Aciltransferase (LCAT) Activity Due to a Novel Homozygous Mutation (Gly-30-Ser) in the LCAT Gene. Hum Mutat. 8:79-82.

64. Fountoulakis N, Lioudaki E, Lygerou D, Dermitzaki EK, Papakitsou I, Kounali V, Holleboom AG, Stratigis S, Belogianni C, Syngelaki P, Stratakis S, Evangeliou A, Gakiopoulou H, Kuivenhoven JA, Wevers R, Dafnis E, Stylianou K. 2019. The P274S Mutation of Lecithin- Cholesterol Acyltransferase (LCAT) and its Manifestations in Large Kindread. AJKD, 20(20): 1-13.

65. Calabresi, L., L. Pisciotta, A. Costantin, I. Frigerio, I. Eberini, P. Alessandrini, M. Arca, G.B. Bon, G. Boscutti, G. Busnach, G. Frascà, L. Gesualdo, M. Gigante, G. Lupattelli, A. Montali, S. Pizzolitto, I. Rabbone, M. Rolleri, G. Ruotolo, T. Sampietro, A. Sessa, G. Vaudo, A. Cantafora, F. Veglia, S. Calandra, S. Bertolini, and G. Franceschini. 2005. The molecular basis of lecithin:cholesterol acyltransferase deficiency syndromes: a comprehensive study of molecular and biochemical findings in 13 unrelated Italian families. Arterioscler Thromb Vasc Biol. 25:1972-1978.

66. Calabresi, L., D. Baldassarre, S. Castelnuovo, P. Conca, L. Bocchi, C. Candini, B. Frigerio, M. Amato, C.R. Sirtori, P. Alessandrini, M. Arca, G. Boscutti, L. Cattin, L. Gesualdo, T. Sampietro, G. Vaudo, F. Veglia, S. Calandra, and G. Franceschini. 2009. Functional lecithin:cholesterol acyltransferase is not required for efficient atheroprotection in humans. Circulation. 120:628-635.

67. Gigante M, Ranieri E, Cerullo G, Calabresi L, Iolascon A, Assmann G, Morrone L, Pisciotta L, Schena FP, Gesualdo L. 2006. LCAT deficiency: molecular and phenotypic characterization of an Italian family. J Nephrol. 19(3):375-81.

68. Taramelli R, Pontoglio M, Candiani G, Ottolenghi S, Dieplinger H, Catapano A, Albers J, Vergani C, McLean J. 1990. Lecithin cholesterol acyl transferase deficiency: molecular analysis of a mutated allele. Hum Genet.85(2):195-9.

69. Frascà, G.M., L. Soverini, E. Tampieri, G. Franceschini, L. Calabresi, L. Pisciotta, P. Preda, A. Vangelista, S. Stefoni, and S. Bertolini. 2004. A 33-year-old man with nephrotic syndrome and lecithin-cholesterol acyltransferase (LCAT) deficiency. Description of two new mutations in the LCAT gene. Nephrol Dial Transplant. 19:1622-1624.

70. Sessa, A., G. Battini, M. Meroni, G. Daidone, I. Carnera, P.L. Brambilla, G. Viganò, F. Giordano, F. Palloti, L. Torri Tarelli, L. Calabresi, M. Rolleri, and S. Bertolini. 2001. Hypocomplementemic type II membranoproliferative glomerulonephritis in a male patient with familial lecithin-cholesterol acyltransferase deficiency due to two different allelic mutations. Nephron. 88:268-272.

71. Conca, P., S. Pileggi, S. Simonelli, E. Boer, G. Boscutti, L. Magnolo, P. Tarugi, S. Penco, G. Franceschini, L. Calabresi, and M. Gomaraschi. 2012. Novel missense variants in LCAT and APOB genes in an Italian kindred with familial lecithin:cholesterol acyltransferase deficiency and hypobetalipoproteinemia. J Clin Lipidol. 6:244-250.

72. Aranda, P., P. Valdivielso, L. Pisciotta, I. Garcia, C. Garca A-Arias, S. Bertolini, G. Marta N-Reyes, Lez-Santos. Gonza, and S. Calandra. 2008. Therapeutic management of a new case of LCAT deficiency with a multifactorial long-term approach based on high doses of angiotensin II receptor blockers (ARBs). Clin Nephrol. 69:213-218.

73. Skretting, G., J.P. Blomhoff, J. Solheim, and H. Prydz. 1992. The genetic defect of the original Norwegian lecithin:cholesterol acyltransferase deficiency families. FEBS Lett. 309:307-310.

74. Strom, E. H., S. Sund, M. Reier-Nilsen, C. Dorje, and T. P. Leren. 2011. Lecithin: Cholesterol Acyltransferase (LCAT) Deficiency: renal lesions with early graft recurrence. Ultrastructural pathology 35: 139-145.

75. Idzior-Waluś, B., J. Sieradzki, G. Kostner, M.T. Malecki, T. Klupa, T. Wesolowska, W. Rostoworowski, J. Hartwich, M. Waluś, A.D. Kiec, and M. Naruszewics. 2006. Familial lecithin-cholesterol acyltransferase deficiency: biochemical characteristics and molecular analysis of a new LCAT mutation in a Polish family. Atherosclerosis. 185:413-420.

76. Castro F., R. Carmo., S.E. Silva., O. Correa., S. Fernández., S. Sampaio., P. Rodriguez- Pereira., A. Praca., J.P. Oliveira. 2017. Novel Missense LCAT Gene Mutation Associated with an Atypical Phenotype of Familia LCAL Deficiency in Two Portuguese Brothers. JMD Reports. 40: 55-62. 
77. Rial-Crestelo D, Santos-Recuero I, Julve J, Blanco-Vaca F, Torralba M. A novel homozygous mutation causing lecithin-cholesterol acyltransferase deficiency in a proband of Romanian origin with a record of extreme gestational hyperlipidemia. J Clin Lipidol. 2017 Nov - Dec;11(6):1475-1479.e3.

78. Cirera, S., J. Julve, I. Ferrer, C. Mainou, R. Bonet, J.M. Martin-Campos, F. Gonzélez-Sastre, and F. Blanco-Vaca. 1998. Molecular diagnosis of lecithin: cholesterol acyltransferase deficiency in a presymptomatic proband. Clin Chem Lab Med. 36:443-448.

79. Recalde, D., A. Cenarro, A.L. García-Otín, D. Gómez-Coronado, F. Civeira, and M. Pocoví. 2002. Analysis of apolipoprotein A-l, lecithin:cholesterol acyltransferase and glucocerebrosidase genes in hypoalphalipoproteinemia. Atherosclerosis. 163:49-58

80. Blanco-Vaca, F., S.J. Qu, C. Fiol, H.Z. Fan, Q. Pao, A. Marzal-Casacuberta, J.J. Albers, I. Hurtado, V. Gracia, X. Pintó, T. Martí, and H.J. Pownall. 1997. Molecular basis of fish-eye disease in a patient from Spain. Characterization of a novel mutation in the LCAT gene and lipid analysis of the cornea. Arterioscler Thromb Vasc Biol. 17:1382-1391.

81. Lamiquiz-Moneo, I., F. Civeira., D. Gómez-Coronado., F. Blanco-Vaca., H.M. Villafuente-Ledesma., M. Gill., N. Amigo., R. Mateo-Gallego., A. Cenarro. 2019. Lipid Profile Rather Than the LCAT Mutation Explains Renal Disease in Familial LCAT Deficiency. J. Clin Med, 8, 1860.

82. Skretting, G., and H. Prydz. 1992. An amino acid exchange in exon I of the human lecithin: cholesterol acyltransferase (LCAT) gene is associated with fish eye disease. Biochem Biophys Res Commun. 182:583-587.

83. Brites FD ${ }^{1}$, Fernández KM, Zunino MJ, Yael MJ, Lardo M, Castro GR, Wikinski RL. 1998. Partial lecithin-cholesterol acyltransferase (LCAT) deficiency syndrome. Medicina (B Aires). 59(1):89-92.

84. Norum, K. Lecithin:Cholesterol Acyltransferase: Symposium on 50-years of Biomedical Research From Its Discovery to Latest Findings. J Lipid Res. 2020 Jun 1;jIr.S120000720.

85. Sampaio C A T L, Nakano H, Saraiva L, Amaral A G, Costa E S, Watanabe E H, Neves P H, Carrascossi H, Silva J A, Guerra A, Braga R M, Santo R, Testagrossa L, Malheiros D, Reis M, Chacra A P, Maranhão R, Balbo B E P, Onuchic L FAmpliação do fenotipo renal associado a deficiência familial de lecitina-colesterol acil-transferase (LCAT). J Bras Nefrol 2017;39(2 Supl. 2):1-54

86. Tobar H.E., L.R. Cataldo., T. González., R. Rodríguez., V. Serrano., A. Ortega., A. Álvarez- Mercado., C. F. Lagos., L. Vicuña., J.P. Miranda., A. Pereira., C. Bravo., C.M, Aguilera., S. Eyheramendy., R. Uauy., A. Martínez., A. Gil., O. Francone., A. Rigotti and J.L. Santos.2019. Identification and Functional Analysis of Missense Mutations on the Lecithin Cholesterol Acyltransferase Gene in a Chilean Patient With Hypoalphalipoproteinemia. Lipis in Health and Disease. 18: 132.

87. Marín G., Torres J., López R., and Andrade R. Síndrome nefrótico secundario a deficiencia de lecitin-colesterol acil-transferasa (LCAT). Acta Médica Colombiana. 31:422-426.

88. Palmiero, P.M., Sbeity, Z., Liebman, J., and Ritch, R. 2009. In vivo imaging of the cornea in a patient with lecithin-cholesterol acyltransferase deficiency. Cornea. 28:1061-1064.

89. Posadas-Sánchez, R., C. Posadas-Romero, W.A. Ocampo-Arcos, M.T. Villarreal-Molina, G. Vargas-Alarcón, E. Antúnez-Argüelles, E. Mendoza-Pérez, G. Cardoso-Saldaña, R. Martínez-Alvarado, A. Medina-Urrutia, and E. Jorge-Galarza. 2014. Premature and severe cardiovascular disease in a Mexican male with markedly low high-density-lipoprotein-cholesterol levels and a mutation in the lecithin:cholesterol acyltransferase gene: a family study. Int $\mathrm{J}$ Mol Med. 33:1570-1576.

90. Mahapatra HS. Co-existence of Classic Familial Lecithin-Cholesterol Acyl Transferase Deficiency and Fish Eye Disease in the Same Family. Indian J Nephrol Nov-Dec 2015;25(6):362-5.

91. Muthusethupathi MA. Familial Lecithin:cholesterol acyltransferase deficiency with renal failure in two siblings. First case report from India. Nephron. 1999 Jan;81(1):89-93.

92. Gopalakrishnan N. Familial Lecithin Cholesterol Acyl Transferase Deficiency with Chronic Kidney Disease. J Assoc Physicians India. 2016. PMID: 27766813.

93. Oliaei F., B. Batebi., R. Tabaripour., H.A. Niaki. 2018. Finding a Very Rare Mutation in Non- Caucasian LCAT Patients from Southwest Asia for the First Time. J. Cell Biochem. 120: 7096-7100.

94. Roshan, B., O.P. Ganda, R. Desilva, R.B. Ganim, E. Ward, S.D. Haessler, E.Y. Polisecki, B.F. Asztalos, and E.J. Schaefer. 2011. Homozygous lecithin:cholesterol acyltransferase (LCAT) deficiency due to a new loss of function mutation and review of the literature. J Clin Lipidol. 5:493-499.

95. Charlton-Menys, V., L. Pisciotta, P.N. Durrington, R. Neary, C.D. Short, L. Calabresi, S. Calandra, and S. Bertolini. 2007. Molecular characterization of two patients with severe LCAT deficiency. Nephrol Dial Transplant. 22:2379-2382.

96. Ustaoglu M. Ocular and Genetic Characteristics Observed in Two Cases of Fish-Eye Disease. Cornea. 2019 Mar;38(3):379-383.

97. Dimick, S.M., B. Sallee, B.F. Asztalos, P.H. Pritchard, J. Frohlich, and E. J. Schaefer. 2014. A kindred with fish eye disease, corneal opacities, marked highdensity lipoprotein deficiency, and statin therapy. J Clin Lipidol. 8:223-230.

98. Kasid, A., J. Rhyne, K.Zeller, H. Pritchard, and M. Miller. 2001. A novel TC deletion resulting in Pro(260)->Stop in the human LCAT gene is associated with a dominant effect on HDL-cholesterol. Atherosclerosis. 156:127-132.

99. Cohen, J.C., R.S. Kiss, A. Pertsemlidis, Y. L. Marcel, R. McPherson, and H.H. Hobbs. 2004. Multiple rare alleles contribute to low plasma levels of HDL cholesterol. Science. 305:869-872.

100. Klein $\mathrm{HG}^{1}$, Lohse P, Duverger N, Albers JJ, Rader DJ, Zech LA, Santamarina-Fojo S, Brewer HB Jr. 1993. Two different allelic mutations in the lecithin:cholesterol acyltransferase (LCAT) gene resulting in classic LCAT deficiency: LCAT (tyr83->stop) and LCAT (tyr156->asn). J Lipid Res. Jan;34(1):49-58.

101. Miller, M., K. Zeller, P.C. Kwiterovich, J.J. Albers, and G. Feulner. 1995. Lecithin: cholesterol acyltransferase deficiency: identification of two defective alleles in fibroblast cDNA. J Lipid Res. 36:931-938.

Page $12 / 21$ 
102. Pavanello $C$ and Calabresi L. Genetic, biochemical, and clinical features of LCAT deficiency: update for 2020. Curr Opin Lipidol 2020, 31:232-237

103. Oldoni F, Baldassarre D, Castelnuovo S, Ossoli A, Amato M, van Capelleveen J, Kees Hovingh G, De Groot E, Bochem A, Simonelli S, Barbieri S, Veglia F, Franceschini G, Kuivenhoven JA, Holleboom AG, Calabresi L. Complete and Partial Lecithin:Cholesterol Acyltransferase Deficiency Is Differentially Associated With Atherosclerosis. Circulation. 2018;138:1000-1007

104. Gomaraschi M, Ossoli A, Castelnuovo S, Simonelli S, Pavanello C, Balzarotti G, Arca M, Di Costanzo A, Sampietro T, Vaudo G, Baldassarre D, Veglia F, Franceschini G, and Calabresi L. 2017. Depletion in LpA-I:A-II particles enhances HDL-mediated endothelial protection in familial LCAT deficiency. Journal of lipid research 58: 994-1001.

105. Haase CL, Tybjærg-Hansen A, Ali Qayyum A, Schou J, Nordestgaard BG, and Frikke-Schmidt R. LCAT, HDL Cholesterol and Ischemic Cardiovascular Disease: A Mendelian Randomization Study of HDL Cholesterol in 54,500 Individuals. J Clin Endocrinol Metab 2012; 97: E248-E256

106. Watson AD, Berliner JA, Hama SY, La Du BN, Faull KF, Fogelman AM, Navab M. 1995. Protective effect of high density lipoprotein associated paraoxonase. Inhibition of the biological activity of minimally oxidized low density lipoprotein. J Clin Invest. 96: 2882-2891

107. James RW, Blatter Garin MC, Calabresi L, Miccoli R, von Eckardstein A, Tilly-Kiesi M, Taskinen MR, Assmann G, Franceschini G. 1998. Modulated serum activities and concentrations of paraoxonase in high density lipoprotein deficiency states. Atherosclerosis. 139: 77-82

108. Berard AM, Clerc M, Brewer B,Jr and Santamarina-Fojo S. 2001. A normal rate of cellular cholesterol removal can be mediated by plasma from a patient with familial lecithin-cholesterol acyltransferase (LCAT) deficiency. Clin Chim Acta. 314: 131-139

109. Rousset X, Vaisman B, Amar M, Sethi AM and Remaley AT. 2009. Lecithin: cholesterol acyltransferase - from biochemistry to role in cardiovascular disease. Current Opinion in Endocrinology, Diabetes \& Obesity. 16:163-171

110. Idzior-Walu’s B, Sieradzki J, Kostner G, Małecki MT, Klupa T, Wesołowskac T, Rostworowski W, Hartwich J, Walús M, Kiéc AD and Naruszewicz M. 2006. Familial lecithin-cholesterol acyltransferase deficiency: Biochemical characteristics and molecular analysis of a new LCAT mutation in a Polish family.

Atherosclerosis. (185):413-420

111. Sorci-Thomas MG, Bhat S and Thomas MJ. 2009. Activation of lecithin:cholesterol acyltransferase by HDL ApoA-I central helices. Clin Lipidol. February ; 4(1): 113-124

112. Obrador GT, Rubilar X, Agazzi E, and Estefan J. The Challenge of Providing Renal Replacement Therapy in Developing Countries: The Latin American Perspective. Am J Kidney Dis. 2016;67(3):499-506

113. Panescu V, Grignon Y, Hestin D, Rostoker G, Frimat L, Renoult E, Gamberoni J, Grignon G, Kessler M. Recurrence of lecithin cholesterol acyltransferase deficiency after kidney transplantation. Nephrology Dialysis Transplantation. 1997;12(11):2430-2.

114. Ossoli A, Lucca F, Boscutti G, Remaley AT \& Calabresi L. Familial LCAT deficiency: from pathology to enzyme replacement therapy. Clinical Lipidology $2015,10: 5,405-413$

115. Homedes, N., and A. Ugalde. 2015. Availability and affordability of new medicines in Latin American countries where pivotal clinical trials were conducted. Bull. World Health Organ. 93: 674-683

\section{Tables}


Table 1:

Systematic analysis of cases with LCAT deficiency

\begin{tabular}{|c|c|c|c|c|c|c|c|c|c|c|c|c|}
\hline $\begin{array}{l}\text { Ethnicity/ } \\
\text { Country }\end{array}$ & REF & $\begin{array}{l}\text { Study } \\
\text { Type }\end{array}$ & $\begin{array}{l}\text { Sample } \\
\text { Size }\end{array}$ & $\begin{array}{l}\text { Median } \\
\text { Age }\end{array}$ & Gender & Phenotype & $\begin{array}{l}\mathrm{HDL}-\mathrm{C} \\
(\mathrm{mg} / \mathrm{dL})\end{array}$ & $\begin{array}{l}\text { Hemolytic } \\
\text { Anemia }\end{array}$ & $\begin{array}{l}\text { Proteinuria/ } \\
\text { Albuminuria }\end{array}$ & $\begin{array}{l}\text { eGFR } \\
<60 \\
\mathrm{~mL} / \mathrm{min}\end{array}$ & $\begin{array}{l}\text { LCAT } \\
\text { Activity } \\
\text { nmol/mL/h }\end{array}$ & $\begin{array}{l}\text { Premat } \\
\text { CHD }\end{array}$ \\
\hline \multicolumn{13}{|l|}{ Asian } \\
\hline \multirow[t]{5}{*}{ Japanese } & \multirow{5}{*}{$\begin{array}{l}19- \\
32\end{array}$} & \multirow{3}{*}{$\begin{array}{l}\text { CR: } \\
13 \\
\text { R: } 1\end{array}$} & 21 & \multirow[t]{3}{*}{44} & $F: 7$ & FLD:18 & \multirow[t]{3}{*}{8.1} & No:2 & No:3 & No:12 & \multirow[t]{3}{*}{7.91} & \\
\hline & & & & & M:11 & FED:3 & & Yes:15 & Yes:13 & Yes:4 & & \\
\hline & & & & & Unk: 3 & & & Unk: 4 & Unk: 5 & Unk: 5 & & \\
\hline & & & & & & & & & & & & No:16 \\
\hline & & & & & & & & & & & & Unk:5 \\
\hline
\end{tabular}

\begin{tabular}{|c|c|c|c|c|c|c|c|c|c|c|c|c|}
\hline Korean & 33 & CR: 1 & 1 & 33 & M:1 & FLD:1 & 12 & Yes:1 & Yes:1 & No:1 & 0.10 & No:1 \\
\hline \multicolumn{13}{|l|}{ African } \\
\hline \multirow[t]{2}{*}{ Morrocan } & \multirow[t]{2}{*}{34} & \multirow[t]{2}{*}{ CR: 1} & \multirow[t]{2}{*}{3} & \multirow[t]{2}{*}{$17,12,3$} & $F: 2$ & \multirow[t]{2}{*}{ FLD:3 } & \multirow[t]{2}{*}{6} & Yes:1 & \multirow[t]{2}{*}{ Yes:3 } & \multirow[t]{2}{*}{ No:3 } & \multirow[t]{2}{*}{0.39} & \multirow[t]{2}{*}{ No:3 } \\
\hline & & & & & M:1 & & & No: 2 & & & & \\
\hline \multicolumn{13}{|l|}{ Caucasian } \\
\hline Australian & 35 & CR: 1 & 1 & 63 & $\mathrm{~F}: 1$ & FED:2 & 4 & No:1 & No:1 & No:1 & 0.80 & No:1 \\
\hline \multirow[t]{3}{*}{ Austrian } & \multirow{3}{*}{$\begin{array}{l}36- \\
37\end{array}$} & \multirow[t]{3}{*}{ CR: 2} & \multirow[t]{3}{*}{4} & \multirow[t]{3}{*}{42} & & FLD:3 & \multirow[t]{3}{*}{11.75} & No:1 & \multirow[t]{3}{*}{ Yes:4 } & & 0.08 & \multirow[t]{3}{*}{ No:4 } \\
\hline & & & & & Unk:2 & $\mathrm{U}: 1$ & & Yes:3 & & Yes:1 & & \\
\hline & & & & & & & & & & Unk:2 & & \\
\hline \multirow[t]{3}{*}{ British } & \multirow{3}{*}{$\begin{array}{l}38- \\
40\end{array}$} & \multirow[t]{3}{*}{ CR: 3} & \multirow[t]{3}{*}{3} & \multirow[t]{3}{*}{58} & $\mathrm{~F}: 1$ & FLD:2 & \multirow[t]{3}{*}{3} & No:2 & No:2 & \multirow[t]{3}{*}{ Normal:3 } & \multirow[t]{3}{*}{0.47} & \multirow{3}{*}{$\begin{array}{l}\text { Present } \\
\text { (FLD, } \\
\text { FED) } \\
\text { No:1 }\end{array}$} \\
\hline & & & & & $M: 2$ & FED:1 & & Yes:1 & Yes:1 & & & \\
\hline & & & & & & & & & & & & \\
\hline \multirow[t]{2}{*}{ Canadian } & \multirow{2}{*}{$\begin{array}{l}41- \\
42\end{array}$} & \multirow[t]{2}{*}{ CR: 2} & \multirow[t]{2}{*}{7} & \multirow[t]{2}{*}{38} & $F: 2$ & FLD:3 & \multirow[t]{2}{*}{6.14} & No:4 & No:4 & No:5 & 4.30 & No:7 \\
\hline & & & & & M:5 & FED:4 & & Yes:3 & Yes:3 & Yes:2 & & \\
\hline
\end{tabular}

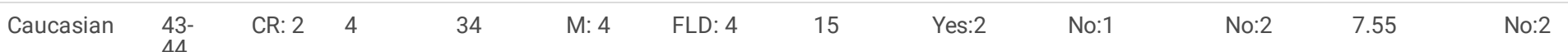




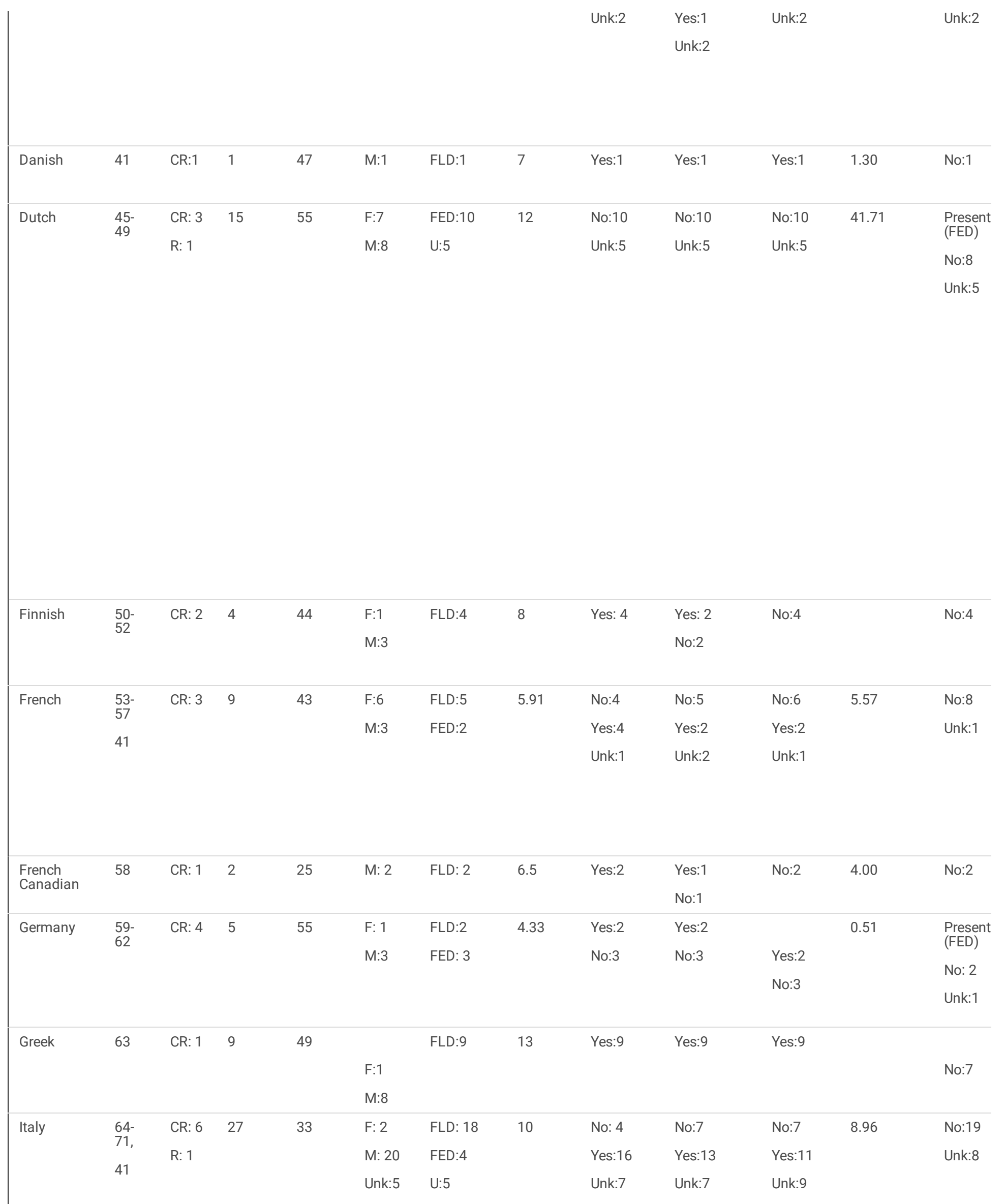




\begin{tabular}{|c|c|c|c|c|c|c|c|c|c|c|c|c|}
\hline \multirow[t]{3}{*}{ Norwegian } & 72,73 & CR: 2 & 9 & 33 & $F: 6$ & FLD:9 & 11 & & Yes:8 & Yes:3 & $0.4,1.3$ & No:6 \\
\hline & & & & & M:3 & & & & No:1 & No:6 & & Unk:3 \\
\hline & & & & & & & & Yes:9 & & & & \\
\hline \multirow[t]{2}{*}{ Polish } & 74 & CR: 1 & 2 & 35 & $\mathrm{~F}: 1$ & FLD:2 & 19 & Yes:2 & Yes:2 & Yes:1 & & No:2 \\
\hline & & & & & $\mathrm{M}: 1$ & & & & & No:1 & & \\
\hline \multirow[t]{2}{*}{ Portuguese } & 75 & CR: 1 & 2 & 39 & & FLD:2 & 15 & Yes:2 & Yes:2 & Yes:2 & & No:2 \\
\hline & & & & & M:2 & & & & & & & \\
\hline \multirow[t]{2}{*}{ Romanian } & 76 & CR:1 & 1 & 33 & $\mathrm{~F}: 1$ & FLD:1 & 12 & & & No:1 & & No:1 \\
\hline & & & & & & & & Yes:1 & Yes:1 & & & \\
\hline \multirow[t]{3}{*}{ Spanish } & 77- & CR: 3 & 12 & 51 & $F: 3$ & FLD:3 & 10.4 & No:2 & No:3 & No:3 & 19.36 & No:5 \\
\hline & & $\mathrm{R}: 1$ & & & $M: 2$ & FED:1 & & Unk:10 & Yes:2 & Yes:2 & & Unk:7 \\
\hline & & & & & Unk:7 & U:8 & & & Unk:7 & Unk:7 & & \\
\hline \multirow[t]{2}{*}{ Swedish } & 81 & CR: 1 & 3 & 68 & $F: 3$ & FED:3 & 7.3 & No:3 & No:3 & No:3 & 2.40 & $\begin{array}{l}\text { Present } \\
\text { (FED) }\end{array}$ \\
\hline & & & & & & & & & & & & No:2 \\
\hline \multicolumn{13}{|c|}{ Latin-American } \\
\hline Argentinian & 82 & CR: 1 & 1 & 63 & $\mathrm{~F}: 1$ & FED:1 & 4 & No:1 & No:1 & No:1 & 2.40 & $\begin{array}{l}\text { Present } \\
\text { (FED) }\end{array}$ \\
\hline \multirow[t]{2}{*}{ Brazilian. } & 83,84 & $\mathrm{R}: 1$ & 38 & 38 & $\mathrm{~F}: 18$ & FLD: 38 & 10 & Yes: 25 & Unk:38 & Yes: 7 & & Unk: 38 \\
\hline & & $A: 1$ & & & M: 20 & & & No: 13 & & Unk:31 & & \\
\hline \multirow[t]{2}{*}{ Chilean } & 85 & CR: 1 & 1 & 36 & $F: 1$ & FLD:1 & 3 & & No:1 & No:1 & & No:1 \\
\hline & & & & & & & & Yes:1 & & & & \\
\hline Colombian & 86 & CR: 1 & 1 & 33 & M:1 & FLD:1 & 4 & Yes:1 & Yes:1 & Yes:1 & & No:1 \\
\hline
\end{tabular}




\begin{tabular}{|llllllllllll} 
Ecuadorian & 87 & CR: 1 & 1 & 60 & F:1 & FED:1 & Unk:1 & No:1 & No:1 & No:1 & Present \\
(FED)
\end{tabular}

\section{Middle East/south asian}

\begin{tabular}{|c|c|c|c|c|c|c|c|c|c|c|c|c|}
\hline Indian & $\begin{array}{l}89- \\
91\end{array}$ & CR: 3 & 6 & 38 & $\begin{array}{l}F: 3 \\
M: 3\end{array}$ & $\begin{array}{l}\text { FLD:4 } \\
\text { FED:2 }\end{array}$ & 13 & $\begin{array}{l}\text { Yes:4 } \\
\text { No:2 }\end{array}$ & $\begin{array}{l}\text { Yes:4 } \\
\text { No:2 }\end{array}$ & $\begin{array}{l}\text { No:2 } \\
\text { Yes:4 }\end{array}$ & 28.00 & No:6 \\
\hline Iranian & 92 & CR: 1 & 8 & 28 & $\begin{array}{l}F: 5 \\
M: 3\end{array}$ & FLD:8 & 28 & No:8 & No:8 & Yes:8 & & No:8 \\
\hline Lebanese & 93 & $\begin{array}{l}\text { CR \& } \\
\text { R: } 1\end{array}$ & 1 & 50 & $M: 1$ & FLD:1 & 7 & Yes:1 & Yes:1 & Yes:1 & & No:1 \\
\hline Pakistani & 94 & CR: 1 & 1 & 33 & $\mathrm{~F}: 1$ & FLD:1 & 13 & Yes:1 & Yes:1 & No:1 & 0.10 & No:1 \\
\hline Turkish & 95 & CR: 1 & 2 & 54 & $\begin{array}{l}\mathrm{F}: 1 \\
\mathrm{M}: 1\end{array}$ & FED:2 & 12 & No:2 & No:2 & No:2 & & $\begin{array}{l}\text { Present } \\
\text { (FED) }\end{array}$ \\
\hline Mixed & & & & & & & & & & & & \\
\hline American & $\begin{array}{l}96- \\
100\end{array}$ & CR: 5 & 6 & 33 & $\begin{array}{l}\mathrm{F}: 2 \\
\mathrm{M}: 3 \\
\text { Unk:1 }\end{array}$ & $\begin{array}{l}\text { FLD:2 } \\
\text { FED:3 } \\
\text { U:1 }\end{array}$ & 5.62 & $\begin{array}{l}\text { No:3 } \\
\text { Yes:2 } \\
\text { Unk:1 }\end{array}$ & $\begin{array}{l}\text { No:3 } \\
\text { Yes:2 } \\
\text { Unk:1 }\end{array}$ & $\begin{array}{l}\text { No:5 } \\
\text { Unk:1 }\end{array}$ & 3.08 & $\begin{array}{l}\text { No:5 } \\
\text { Unk:1 }\end{array}$ \\
\hline
\end{tabular}

Abbreviations. REF: reference. eGFR: estimated glomerular filtration rate (MDRD equation), CHD: coronary heart disease, CR: case report, R: review, A: abstract, FLD: familial LCAT deficiency, FED: Fish-eye disease, U: unclassified, Unk: unknown F: female, M: male, EX: exon. 
Table 2:

Systematic analysis: Characteristics of FLD and FED cases

\begin{tabular}{|c|c|c|c|c|c|}
\hline \multirow{2}{*}{\begin{tabular}{|l|} 
\\
AGE (years)
\end{tabular}} & & $\begin{array}{l}\text { Total } n=216 \\
\text { (Unclassified } n=20 \text { ) }\end{array}$ & $\begin{array}{l}\text { FLD } \\
(n=153,70.8 \%)\end{array}$ & $\begin{array}{l}\text { FED } \\
(n=43,19.9 \%))\end{array}$ & p \\
\hline & & $44.8( \pm 15.6)$ & $40.2( \pm 13.8)$ & $53.0( \pm 15.6)$ & $<0.001$ \\
\hline \multirow{4}{*}{$\begin{array}{l}\text { GENDER }(n=203) \\
(\text { Unknown=13) }\end{array}$} & MALE & 119 & 93 & 18 & 0.17 \\
\hline & & $(58.6 \%)$ & $(60.7 \%)$ & $(41.8 \%)$ & \\
\hline & FEMALE & 84 & 57 & 23 & \\
\hline & & $(41.3 \%)$ & $(37.2 \%)$ & $(53.4 \%)$ & \\
\hline \multirow{4}{*}{$\begin{array}{l}\text { PREMATURE } \\
\text { CHD }(n=148) \\
\text { (Unknown=68) }\end{array}$} & YES & 13 & 1 & 12 & $<0.001$ \\
\hline & & $(6.01 \%)$ & $(0.65 \%)$ & $(27.9 \%)$ & \\
\hline & NO & 135 & 112 & 16 & \\
\hline & & $(62.5 \%)$ & (73.2\%) & $(37.2 \%)$ & \\
\hline \multirow{2}{*}{\multicolumn{2}{|c|}{$\mathrm{HDL}-\mathrm{C} \mathrm{mg} / \mathrm{dL}^{\mathrm{b}}$}} & 7 & 7.0 & 6.7 & 0.272 \\
\hline & & $(4-12)$ & $(4-12)$ & $(3.9-9.7)$ & \\
\hline \multirow{2}{*}{\multicolumn{2}{|c|}{ Tryglicerides $\mathrm{mg} / \mathrm{dL}^{\mathrm{b}}$}} & 206 & 185 & 283 & 0.165 \\
\hline & & $(138-380)$ & $(121-380)$ & $(164-528)$ & \\
\hline \multirow{2}{*}{\multicolumn{2}{|c|}{$\begin{array}{l}\text { LCAT ACTIVITY } \mathrm{nmol} / \mathrm{mL} / \mathrm{h}^{\text {b }} \\
(\mathrm{n}=78)\end{array}$}} & 1.50 & 0.1 & 2.1 & 0.013 \\
\hline & & $(0.00-7.02)$ & $(0.0-2.1)$ & $(0.9-3.5)$ & \\
\hline \multirow{4}{*}{$\begin{array}{l}\text { eGFR <60 }(n=184) \\
(\text { Unknown }=32)\end{array}$} & YES & 65 & 62 & 3 & 0.00 \\
\hline & & $(35.3 \%)$ & $(40.5 \%)$ & $(6.9 \%)$ & \\
\hline & NO & 87 & 48 & 38 & \\
\hline & & $(47.2 \%)$ & $(31.3 \%)$ & $(88.3 \%)$ & \\
\hline \multirow{4}{*}{$\begin{array}{l}\text { PROTEINURIA } \\
\text { MICROALBUMINURIA } \\
(n=177) \\
(\text { Unknown =29) }\end{array}$} & YES & 84 & 83 & 1 & 0.00 \\
\hline & & $(47.4 \%)$ & $(54.2 \%)$ & $(2.32 \%)$ & \\
\hline & No & 64 & 24 & 40 & \\
\hline & & $(36.1 \%)$ & $(15.6 \%)$ & (93.02\%) & \\
\hline \multirow{4}{*}{$\begin{array}{l}\text { HEMOLYTIC ANEMIA } \\
(n=215) \\
(\text { Unknown=30) }\end{array}$} & YES & 116 & 115 & 1 & 0.00 \\
\hline & & $(53.9 \%)$ & $(75.1 \%)$ & $(2.32 \%)$ & \\
\hline & NO & 69 & 28 & 20 & \\
\hline & & (32.1\%) & $(18.3 \%)$ & $(46.5 \%)$ & \\
\hline
\end{tabular}

Abbreviations. FLD: Familial LCAT deficiency. FED: Fish eye disease. CHD: coronary heart disease. eGFR: estimated glomerular filtration rate (MDRD equation).

${ }^{\mathrm{a}}$ media $( \pm \mathrm{DE})^{\mathrm{b}}$ mediana (IIC) 
Table 3:

Characteristics of Latin America population

\begin{tabular}{|c|c|c|c|c|c|c|c|c|}
\hline Country & $\begin{array}{l}\text { Exon } \\
\text { mutation }\end{array}$ & $\begin{array}{l}\text { Nucleotide } \\
\text { change }\end{array}$ & Phenotype & Age & Gender & $\begin{array}{l}\text { HDL-C } \\
\mathrm{mg} / \mathrm{dL}\end{array}$ & $\begin{array}{l}\mathrm{TG} \\
\mathrm{mg} / \mathrm{dL}\end{array}$ & $\begin{array}{l}\text { LCAT } \\
\text { activity } \\
\text { nmol/mL/h }\end{array}$ \\
\hline Argentinean & Unknown & Unknown & Unclassified & 63 & $\mathrm{~F}$ & 4 & 765 & 2.4 \\
\hline \multirow[t]{3}{*}{ Brazilian } & Ex 5 & c. 679 A>T & \multirow[t]{3}{*}{38 FLD } & \multirow[t]{3}{*}{38} & \multirow{3}{*}{$\begin{array}{l}18 \mathrm{~F} \\
20 \mathrm{M}\end{array}$} & \multirow[t]{3}{*}{$<10$} & & \multirow[t]{3}{*}{-} \\
\hline & Ex 6 & c. $803 \mathrm{G}>\mathrm{A}$ & & & & & & \\
\hline & & c.893 C>T & & & & & & \\
\hline \multirow[t]{2}{*}{ Chilean } & Ex 6 & c. $997 G>A$ & \multirow[t]{2}{*}{ FLD } & \multirow[t]{2}{*}{36} & \multirow[t]{2}{*}{$\mathrm{F}$} & \multirow[t]{2}{*}{3} & \multirow[t]{2}{*}{387} & \multirow[t]{2}{*}{-} \\
\hline & Ex 6 & c. $1210 A>G$ & & & & & & \\
\hline Colombian & - & - & FLD & 33 & M & 4 & 1260 & - \\
\hline Ecuadorian & - & - & FLD & 60 & $\mathrm{~F}$ & & & - \\
\hline $\begin{array}{l}\text { Mexican Mestizo ( } 1 \text { proband and } 2 \text { other members } \\
\text { of same family) }\end{array}$ & Ex 1 & Trp8* & FLD & 37 & $\mathrm{~F}$ & 15 & 300 & 3.70 \\
\hline \multirow[t]{2}{*}{ Mexican Mestizo } & Ex 1 & c.101dupC & \multirow[t]{2}{*}{ FED } & \multirow[t]{2}{*}{70} & \multirow[t]{2}{*}{$\mathrm{F}$} & \multirow[t]{2}{*}{12} & \multirow[t]{2}{*}{334} & \multirow[t]{2}{*}{4.20} \\
\hline & Ex 1 & c. $110 \mathrm{C}>\mathrm{T}$ & & & & & & \\
\hline Mexican Mestizo & Ex 1 & c. $110 \mathrm{C}>\mathrm{T}$ & FLD & 34 & $M$ & 2 & 597 & 2.10 \\
\hline Mexican Mestizo & Ex 4 & c. $490 \mathrm{C}>\mathrm{T}$ & FLD & 29 & $\mathrm{~F}$ & 4 & 186 & - \\
\hline Total & & 10 & 48 & - & - & - & & - \\
\hline
\end{tabular}

Abbreviations. HDL-C: high density lipoprotein cholesterol. 
Biochemical results of probands 1,2 and 3 and their kindred

\begin{tabular}{|c|c|c|c|c|c|c|c|c|c|c|}
\hline & & TG & $\begin{array}{l}\text { Total } \\
\text { chol }\end{array}$ & $\begin{array}{l}\mathrm{HDL}- \\
\mathrm{C}\end{array}$ & $\begin{array}{l}\text { LDL- } \\
\text { C }\end{array}$ & $\begin{array}{l}\text { Apo } \\
\text { A1 }\end{array}$ & $\begin{array}{l}\text { Apo } \\
\text { B }\end{array}$ & $\begin{array}{l}\text { LCAT } \\
\text { activity \% }\end{array}$ & $\begin{array}{l}\text { Specific LCAT Activity } \\
(\mathrm{nmol} / \mathrm{mL} / \mathrm{h})\end{array}$ & $\begin{array}{l}\text { PON-1 } \\
\mathrm{mU} / \mathrm{ml} / \mathrm{h} \\
\text { (Control } \\
100.77)\end{array}$ \\
\hline \multirow{7}{*}{$\begin{array}{l}\text { PROBAND } \\
1\end{array}$} & Father (II-1) & 112 & 168 & 37 & 109 & 132 & 92.5 & 2.70 & 25.63 & 100.5 \\
\hline & Mother (II-2) & 188 & 203 & 38 & 127 & 135 & 122 & 3.18 & 30.19 & 62.6 \\
\hline & Proband (37 yrs) (III-7) & 300 & 153 & 15 & 78 & 44 & 113 & 0.4 & 3.79 & 27.8 \\
\hline & \multicolumn{10}{|l|}{$(\mathrm{III}-2)$} \\
\hline & $\begin{array}{l}\text { Brother2 (33 yrs) } \\
(\text { III-1) }\end{array}$ & 589 & 313 & 17 & 178 & 47.2 & 114 & 0.5 & 4.74 & 53.0 \\
\hline & $\begin{array}{l}\text { Brother3 (22 yrs) } \\
(\text { III-10) }\end{array}$ & 117 & 161 & 26 & 112 & 91.6 & 102 & 2.42 & 22.98 & 97.0 \\
\hline & $\begin{array}{l}\text { Sister } \quad(45 \mathrm{yrs}) \\
(\mathrm{III}-5)\end{array}$ & 177 & 168 & 23 & 110 & - & - & 3.82 & 36.27 & 81.7 \\
\hline \multirow{6}{*}{$\begin{array}{l}\text { PROBAND } \\
2\end{array}$} & Proband (II-1) & 334 & 150 & 12 & 71 & 48.7 & 109 & & 4.2 & \\
\hline & Daughter 1 (III-1) & 290 & 196 & 30 & 108 & 131 & 116 & & 55 & \\
\hline & Daughter 2 (III-2) & 191 & 157 & 25 & 94 & 123 & 108 & & 52.7 & \\
\hline & $\begin{array}{l}\text { Granddaughter (mother is } \\
\text { daughter 1) (IV-1) }\end{array}$ & 59 & 180 & 81 & 87 & 210 & 52.7 & & & \\
\hline & $\begin{array}{l}\text { Grandson (mother is daughter } 1 \text { ) } \\
\text { (IV-2) }\end{array}$ & 450 & 240 & 48 & 102 & 169 & 121 & & & \\
\hline & $\begin{array}{l}\text { Grandson (mother is daughter 2) } \\
\text { (IV-4) }\end{array}$ & 85 & 162 & 46 & 99 & 157 & 92.3 & & & \\
\hline \multirow{2}{*}{$\begin{array}{l}\text { PROBAND } \\
3\end{array}$} & Proband (II-1) & 186 & 117 & 4 & 59 & & & & 7.3 & \\
\hline & Father (II-1) & 257 & 168 & & & & & & & \\
\hline
\end{tabular}

Abbreviations. TG: triglycerides HDL-C: high density lipoprotein cholesterol. LDL-C: low density lipoprotein cholesterol. ApoA1: apolipoproten A1 ApoB: apolipoprotein B.

\section{Figures}




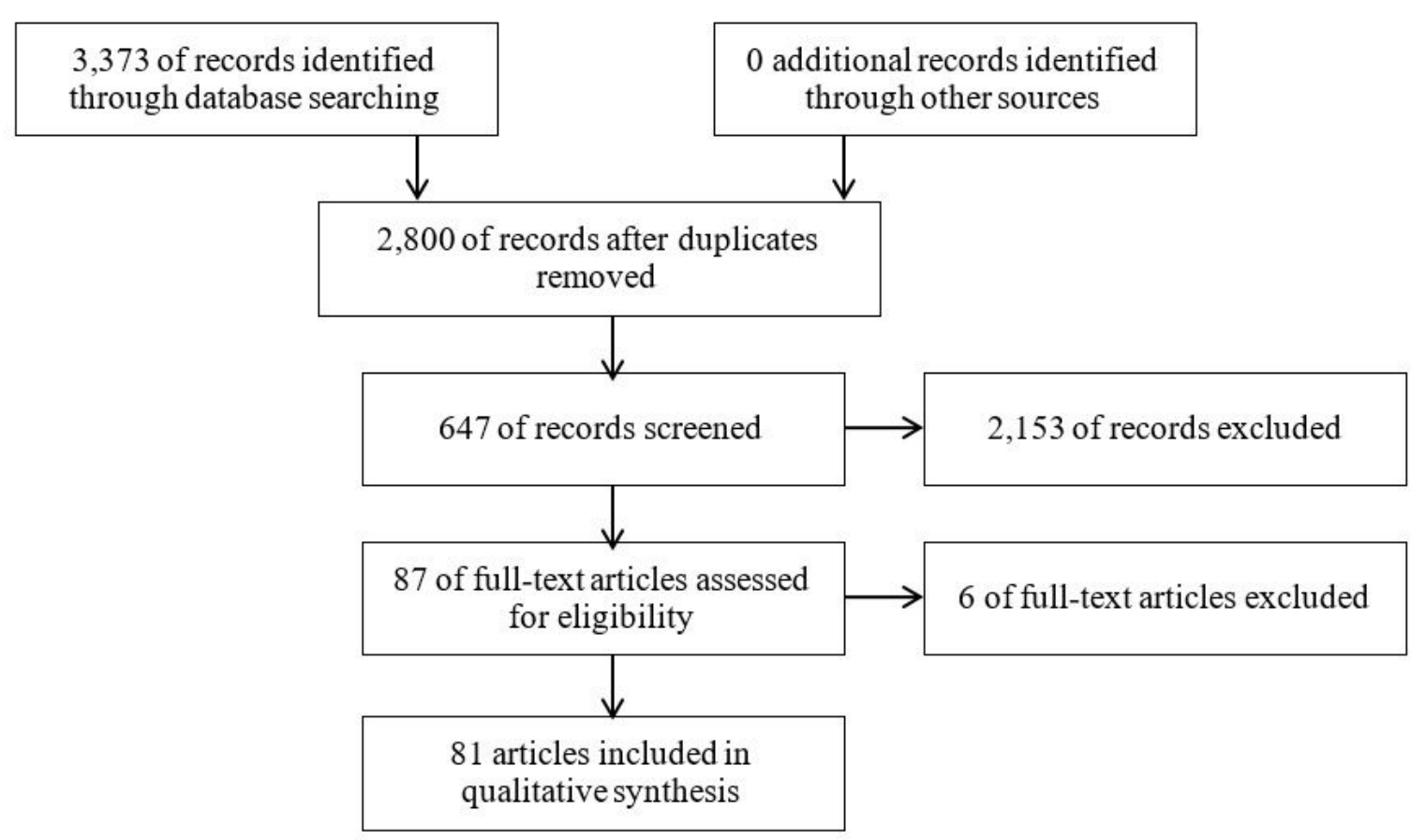

Figure 1

Systematic review

\section{Supplementary Files}

This is a list of supplementary files associated with this preprint. Click to download.

- SupplementaryFiguresandtablesMARZ02021.docx 